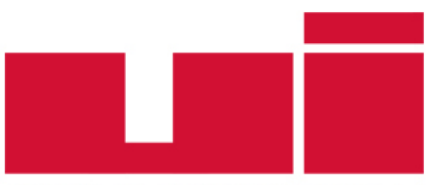

ULUUSLARARASIILIŞKiLER

Akademik Dergi

Yayın ilkeleri, izinler ve abonelik hakkında ayrıntılı bilgi:

E-mail: bilgi@uidergisi.com

Web: www.uidergisi.com

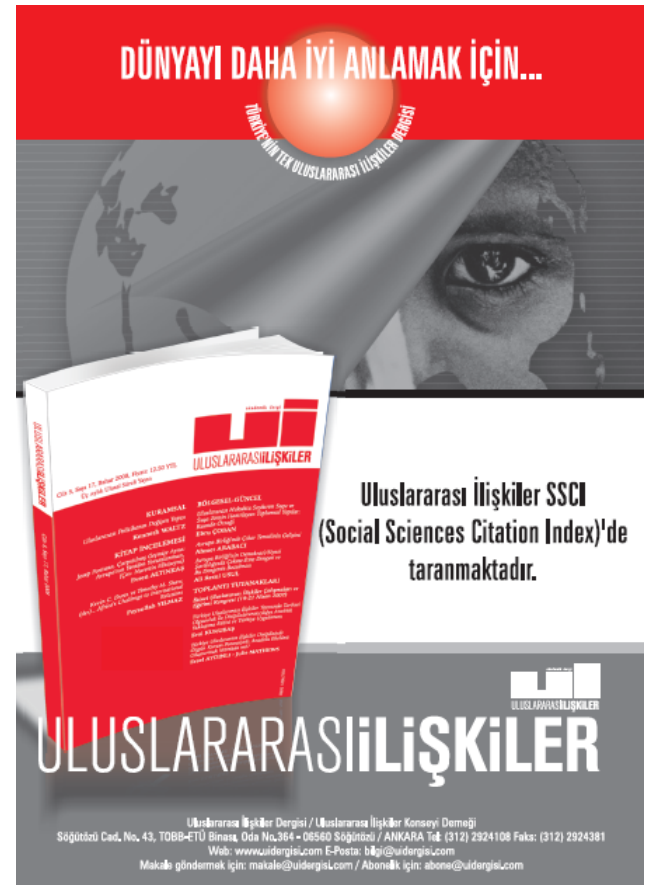

Avrupa Insan Hakları Mahkemesi ve Geçiş Dönemi Adaleti İlişkisi: Silahlı Çatışma Süreçlerine İlişkin Verilen Kararlar Üzerinden Bir Değerlendirme

\author{
Serdar GÜLENER* \\ * Doç. Dr., Sakarya Üniversitesi, Siyaset Bilimi ve Kamu \\ Yönetimi Bölümü
}

Bu makaleye atıf için: Gülener, Serdar, “Avrupa İnsan Hakları Mahkemesi ve Geçiş Dönemi Adaleti İlişkisi: Silahlı Çatışma Süreçlerine İlişkin Verilen Kararlar Üzerinden Bir Değerlendirme", Uluslararası Illişkiler, Cilt 11, Sayı 41 (Bahar 2014), s. 3-28.

Bu makalenin tüm hakları Uluslararası İlişkiler Konseyi Derneği’ne aittir. Önceden yazılı izin alınmadan hiç bir iletişim, kopyalama ya da yayın sistemi kullanılarak yeniden yayımlanamaz, çoğaltılamaz, dağıtılamaz, satılamaz veya herhangi bir şekilde kamunun ücretli/ücretsiz kullanımına sunulamaz. Akademik ve haber amaçlı kısa alıntılar bu kuralın dışındadır.

Aksi belirtilmediği sürece Uluslararası Illişkiler'de yayınlanan yazılarda belirtilen fikirler yalnızca yazarına/yazarlarına aittir. UİK Derneğini, editörleri ve diğer yazarları bağlamaz. 


\title{
Avrupa İnsan Hakları Mahkemesi ve Geçiş Dönemi Adaleti İlişkisi: Silahlı Çatışma Süreçlerine İlişkin Verilen Kararlar Üzerinden Bir Değerlendirme
}

\author{
Serdar GÜLENER*
}

\section{ÖZET}

$\mathrm{Bu}$ çalışmada uluslararası ilişkiler disiplinin temel inceleme alanlarından biri olan silahlı çatışma süreçlerinde ortaya çıkan insan hakları ihlalleri Avrupa İnsan Hakları Mahkemesi perspektifinden değerlendirilmektedir. Mahkemenin bu ihlallere yaklaşımı çatışma sonrası yeniden inşayı sağlamayı hedefleyen geçiş dönemi adaleti penceresinden incelenmektedir. $\mathrm{Bu}$ çerçevede öncelikle, silahlı çatışma ve geçiş dönemi adaleti kavramları gözden geçirilmektedir. $\mathrm{Bu}$ kavramları somutlaştırmak için Avrupa coğrafyasında yaşanmış olan ya da halen yaşanan silahlı çatışmalar, geçiş dönemi adaleti aracıllğıyla analiz edilmektedir. Bunun sonucunda Avrupa İnsan Hakları Mahkemesinin silahlı çatışmalarda yaşanan insan hakları ihlallerinin giderilmesinde doğrudan bir geçiş dönemi adaleti mekanizması olmadığı ancak çatışma süreçlerinin neden olduğu yıkıcı etkilerin onarımında zaman zaman ulusal makamlar üzerinde etkide bulunduğu ortaya konulmaktadır.

Anahtar Kelimeler: Silahlı Çatışmalar, Avrupa İnsan Hakları Mahkemesi (AİHM), Avrupa İnsan Hakları Sözleşmesi (AİHS), Geçiş Dönemi Adaleti, Çatışma Sonrası Toplum.

\section{The Relationship between the European Court of Human Rights and Transitional Justice: A Review of Court Cases Related to Armed Conflicts}

\begin{abstract}
This paper examines role of the European Court of Human Rights in dealing with human rights abuses following armed conflicts, as one of the most notable fields in international relations. In this framework, it begins by reviewing the concepts of armed conflicts and transitional justice. To make it more concrete, cases of armed conflict across Europe are analyzed through the lens of transitional justice. It is found that practices of ECtHR are not directly a means of transitional justice, but they have effects on national authorities in the process of restitution.
\end{abstract}

Keywords: Armed Conflicts, European Court of Human Rights (ECtHR), European Convention of Human Rights (ECHR), Transitional Justice, Post-Conflict Societies.

\footnotetext{
* Doç. Dr., Anayasa Mahkemesi Raportörü/Siyaset Bilimi ve Kamu Yönetimi Bölümü, Sakarya Üniversitesi, Sakarya. E-posta: serdargulener@gmail.com. Bu makalede yer alan görüş ve düşünceler yazarın bağlı olduğu kurumun görüşlerini yansıtmaz.
} 


\section{Giriş: Silahlı Çatışma Kavramı}

Silahlı çatışmalar, ağır insan hakları ihlallerine yol açan süreçler olarak uluslararası hukukun ve uluslararası insancıl hukukun temel ilgi alanlarından birini meydana getirmektedir. Uluslararası hukuk açısından silahlı çatışma kavramının çerçevesinin çizilmesi büyük ölçüde antlaşmalar hukukunun gelişimine paralel bir seyir izlemiştir. ${ }^{1} \mathrm{Bu}$ kapsamda 1949 tarihli Cenevre Sözleşmeleri ve bu Sözleşmelere 1977 yılında eklenen I. ve II. Protokol ${ }^{2}$, kavramın hukuksal bir terim olarak uluslararası hukuktaki yerini almasını sağlamıştır. ${ }^{3}$

Silahlı çatışmalar, ortaya çıkardıkları sonuçlar itibarıyla sadece insan haklarının ihlal edilmesine değil aynı zamanda sosyal, ekonomik ve siyasi olarak ciddi toplumsal yıkımların da oluşmasına neden olmaktadır. Bunun kaçınılmaz sonucu ise topluma hâkim olan moral uzlaşının zedelenmesidir. Ortaya çıkan bu olumsuzlukların aşılması noktasında hem uluslararası hukuk hem de uluslararası insancıl hukuk çeşitli koruma mekanizmaları geliştirmiştir. ${ }^{4}$ Ancak söz konusu mekanizmalar yasal bir mevzuat aracılığıyla çatışma ortaya çıktıktan sonra bazı yaptırımların uygulanması veya çatışma çıkmadan bunun engellenebilmesini amaçlamaktadır. Saf hukuksal bir perspektiften bakıldığında oldukça kullanışlı görünen bu mekanizmaların etkinliği, çatışmaların sosyolojik ve siyasi boyutları dikkate alındığında ihlallerin giderilmesi noktasında çözüm getirmekten uzak gözükmektedir. Oysa uzlaşıya dayalı bir toplumsal yeniden inşanın sağlanması; psikolojik ve sosyolojik boyutları dikkate alan bir yaklaşımı zorunlu kılmaktadır. Geçiş dönemi adaleti (GDA) bu ihtiyacın bir ürünü olarak çatışmacı süreçlerden barışçı ve uzlaşmacı süreçlere geçişte bir köprü görevi görmektedir.

Yakın bir zaman önce Avrupa İnsan Hakları Mahkemesi (AİHM) tarafından verilen Maktouf and Damjanović v. Bosna Hersek ${ }^{5}$, Janowiec v. Rusya ${ }^{6}$ ve Benzer ve diğerleri v. Türkiye ${ }^{7}$ kararları, Mahkemenin silahlı çatışma süreçlerine dair yaklaşımının yeniden değerlendirilmesi ve geçmişte yaşanan insan hakları ihlalleri ile hesaplaşılmasında üstlendiği rol konusunda önemli bir hatırlatma olarak görülebilir.

1 Sylvain Vite, "Typology of Armed Conflicts In International Humanitarian Law: Legal Concepts And Actual Situtuations", International Review of the Red Cross, Cilt 91 No. 873 Mart 2009, s.70.

2 Tam adı "Savaş Mağdurlarının Korunması Hakkında Cenevre Sözleşmeleri” ve ek protokollerinin Türkçe çevirisi için bkz. "12 Ağustos 1949 Tarihli Cenevre Sözleşmeleri ve Ek Protokolleri”, Yay. Haz. Melike Batur Yamaner, A. Emre Öktem, Bleda Kurtdarcan ve Mehmet C. Uzun, Galatasaray Üniversitesi Hukuk Fakültesi Yayınları, http://www.icrc.org/eng/home/languages/turkish/files/ sozlesmeleri-protokolleri-conventions-protocols.pdf (Erişim Tarihi 26 Temmuz 2013).

3 Josef Mrázek, "Armed Conflicts and Use of Force", Czech Yearbook of Public E Private International Law, 2010/1, s. 88-89.

4 Bu mekanizmalar için bkz. United Nations Human Rights Office of the High Commissioner, International Legal Protection of the Human Rights in Armed Conflict, New York and Geneva, 2011.

5 Maktouf and Damjanoviæ v. Bosna Hersek, No. 2312/8 and 34179/08, 18 Haziran 2013.

6 AİHM kararı, Janowiec ve diğerleri v. Rusya, No. 55508/07 ve 29520/09, 21 Ekim 2013.

7 AİHM kararı, Benzer ve diğerleri v. Türkiye, No.23502/06, 12 Kasım 2013. 
Bugün GDA ile AİHM kararları arasındaki ilişkiyi analiz eden çalışmaların sayısı oldukça sınırlı olmakla birlikte yakın dönemde bu ilginin artmaya başladığı söylenebilir. ${ }^{8}$ Bununla beraber silahlı çatı̧̧ma süreçleri ile AİHM ilişkisini doğrudan ele alan çalışmalar ${ }^{9}$ genel olarak Avrupa İnsan Hakları Sözleşmesinnin (AİHS) yetki alanı üzerinde dururken, bazı çalı̧malar ise özellikle mülkiyet hakk1, eski haline getirme (restitution) veya tazminat kavramlarını merkeze alan kararlar ekseninden bu ilişkiyi değerlendirmektedir. ${ }^{10}$ Baştan belirtilmelidir ki, bu çalışmada silahlı çatışma süreçleri ile AİHM kararları arasındaki ilişkiden faydalanılacaktır. Ancak çalışmanın odaklandığı nokta, GDA'nın bu ilişki içindeki yeridir. Başka bir deyişle silahlı çatışma süreçlerinden uzlaşmacı/barışçı süreçlere geçişte adalet merkezli bir dönüşüm söylemini temsil eden GDA esas alınarak, Avrupa insan hakları sisteminin en önemli aktörü olan AİHM'nin kararları incelenecek ve silahlı çatışmalar sonrasında üstlen(eme)diği rolün fotoğrafı çekilecektir. Bu yönüyle çalı̧̧ma, uluslararası ilişkiler disiplininin temel inceleme alanlarından biri olan silahlı çatışma süreçlerine insan hakları penceresinden bakmayı amaçlamaktadır. Bunu yaparken sosyoloji, psikoloji, siyaset bilimi ve uluslararası hukuk gibi disiplinlerin etrafinda şekillenmiş bir kavram olan GDA kullanılarak, uluslararası ilişkiler alanına disiplinlerarası bir katkı yap1lması hedeflenmektedir.

Öncelikle GDA'nın insan hakları açısından neyi ifade ettiği açıklanacak, ardından AİHM'nin silahlı çatı̧̧ma süreçlerine ilişkin verdiği kararlardan yola çıkılarak, nasıl bir GDA yaklaşımı ortaya koyduğu tespit edilmeye çalışılacaktır. Bu amaçla kararlarının fazlalı̆̆ı da dikkate alınarak davaların örneklemi AİHM tarafından yayımlanan "çatışma süreçleri”"11 başlıklı bilgi notundaki kararlar ile sınırlandırılacaktır.

8 Bu konudaki önemli bir çalışma için bkz. Eva Brems, "Transitional Justice in the Case of the European Court of Human Rights", The International Journal of Transitional Justice, Vo. 5, 2011, s. 282-303.

9 Bu konudaki başlıca çalışmalar için bkz. Antoine Buyse, Margins of Conflict: The ECHR and Transitions to and from Armed Conflict, Intersentia, 2010; William Abresch, "A Human Rights Law of Internal Armed Conflict: The European Court of Human Rights in Chechnya", European Journal of International Law, Cilt 16, No. 4, 2005, s.741-767.

10 Bu konudaki başlıca çalışmalar için bkz. Tom Allen, "Restitution and Transitional Justice in the European Court of Human Rights", Columbia Journal of European Law, Cilt 13, No.1, 2007, s.1-46; Antoine Christian Buyse, Post-conflict Housing Restitution: the European Human Rights Perspective, with a Case Study on Bosnia and Herzigovina, Intersentia, 2008; Antoine Buyse, "Home Sweet Home? Restitution in Post-Conflict Bosnia and Herzegovina”, Netherlands Quarterly of Human Rights, Cilt 27, No.1, s.9-26; Bernadette Atuahene, Property and Transitional Justice, UCLA Law Review, Disc 65, 2010, s.65-93; Tom Allen, "Transitional Justice and the Right to Property under the European Convention on Human Rights", Stellenbosch Law Review 3, s.413-430; James A. Sweeney, "Restorative Justice and Transitional Justice at the ECHR", International Criminal Law Review, No.12, 2012, s.313-337.

11 Temmuz 2013 tarihinde güncellenen sürümü için bkz. ECHR Press Unit, Armed Conflict Factsheet, http://www.echr.coe.int/Documents/FS_Armed_conflicts_ENG.pdf (Erişim Tarihi 28 Temmuz 2013). 


\section{Geçiş Dönemi Adaleti: Kavramsal Bir Çerçeve}

İster devletler arasında olsun isterse devletin kendi içinde, çatı̧̧ma süreçlerinde yaşanan insan hakları ihlallerinin meydana getirdiği ağır yıkım, toplumsal zihin dünyasında travmatik sonuçlara yol açtığı için toplumun geleceği üzerinde ipotek kurma potansiyeli taşımaktadır. Çatı̧̧ma sona erdiğinde veya sona erdirilmesi yönünde bir irade baş gösterdiğinde, toplumsal uzlaşının önündeki muhtemel engellerin başında, yara almış ve tatmin edilememiş toplumsal vicdan gelmektedir. GDA, bir yandan geçmişle adilane bir biçimde hesaplaşarak yaşanan acılara ilişkin hakikatlerin ortaya çıkmasını sağlamakta, diğer yandan da başta tazminat olmak üzere çeşitli yeniden kazanım yollarını devreye sokarak, toplum vicdanına adalet duygusunun egemen kılınmasına yardımcı olmaktadır. Bu nedenle birçok ülke tarafından demokrasinin inşası ve konsolidasyonunda oldukça etkili bir araç olarak kullanıldığı söylenebilir. ${ }^{12}$

Doktrinde GDA’nın farklı boyutlarıyla ele alındığı görülmekle birlikte, yapılan tanımlamalarda ortak olan nokta, çatışmanın özelde bireyler genelde ise toplumda yarattı̆̆ 1 yıkıcı etkinin ancak hukuk devleti araçlarının hayata geçirilmesi ile onarılabileceğidir. ${ }^{13}$

Birleşmiş Milletler' in (BM) GDA tanımlaması, mevcut uygulamalara yön vermesi ve GDA sürecinin işleyişine ilişkin öneriler getirmesi açısından önemlidir. GDA, BM tarafından yayınlanan kılavuz notta: Ağır insan hakları ihlallerine uğramış toplumlarda adalete ve uzlaşıya hizmet eden bir hesap verebilirliğin sağlanması adına kullanılan her türlü aracı ve yöntemi ifade etmektedir. ${ }^{14}$ Bunlar, hesap verme, cezailik, onarıc1lk, yeniden kazandırma, hafiza gibi çok boyutlu bir kavramsal temel üzerine inşa edilmektedir. Ceza yargılamaları, hakikate ulaşımın sağlanması, tazminat programları ve kurumsal reformlar (temizlik politikaları) gibi yargısal veya yargısal olmayan birçok yöntem ya da mekanizma GDA'nın temel bileşenleri olarak kabul edilmektedir. ${ }^{15}$

Ceza yarğlamaları yöntemiyle soykırım, insanlığa karşı işlenen suçlar, savaş suçları gibi ağır insan hakları ihlallerinden sorumlu olanların cezai olarak hesap vermeleri sağlanmaktadır. ${ }^{16}$ İkinci Dünya Savaşı sonrası kurulan Nürnberg ve Tokyo Uluslararası Ceza Mahkemeleri bu yöntemin ilk örneklerini teşkil etmiştir. Günümüzde Ruanda ve Eski

12 Serdar Gülener, "Çatışmacı Bir Geçmişten Uzlaşmacı Bir Geleceğe Geçişte Adalet Arayış1: Geçiş Dönemi Adaleti ve Mekanizmalarına Genel Bir Bakış”, Uluslararası Hukuk ve Politika, USAK Yayınları, Cilt 8, Sayı 32, s.45.

$13 \mathrm{Bu}$ alandaki başlica çalışmalar için bkz. Transitional Justice: How Emerging Democracies Reckon with Former Regimes, Cilt 1-2-3, Neil J. Kritz, United States Institute of Peace, 1995; Ruti G. Teitel, Transitional Justice, Oxford University Press, New York, 2000; Jon Elster, Closing the Books: Transitional Justice in Historical Perspective, Cambridge University Press, New York, 2004; Louis Bickford, "Transitional Justice?", The Encyclopedia of Genocide and Crimes Against Humanity, Cilt 3, Macmillian Reference, 2004, s.1045-1047.

14 Guidance Note of the Secrateray General, United Nations Approach to Transitional Justice, 2010, s. 2, http://www.unrol.org/files/TJ_Guidance_Note_March_2010FINAL.pdf (Erişim Tarihi 28 Haziran 2013).

15 Ibid, s. 2.

16 Bkz. Office of the United Nations High Commisioner for Human Rights, Rule of Law Tools of Post Conflict States: Prosecution Initiatives, New York and Geneva, 2006. 
Yugoslavya Uluslararası Ceza Mahkemeleri ve Uluslararası Ceza Mahkemesi bu amaçla oluşturulan yargı yerleri olarak öne çıkmaktadır. ${ }^{17}$ Hakikate ulaşma; ceza yargilamalarının eksikliklerini ortadan kaldırmayı amaçlamaktadır. Çünkü geçmişte yaşanan ihlallerinin sorumlularının cezalandırılması toplum vicdanını rahatlatmakla beraber, toplumsal uzlaşının sağlanmasında yetersiz kalma riski taşımaktadır. ${ }^{18}$ Oysa bir bütün olarak toplumsal uzlaşı, geçmişte yaşanan gerçekler üzerinden yapılacak bir muhasebe ile mümkün olacaktır. Böylesi bir ihtiyacın ürünü olan "hakikat komisyonları", çatışmanın tüm tarafları bir araya getirerek hakikatlerin kamuya açı bir biçimde tartı̧̧ılmasını ve tarafların uzlaşmasını sağlamaktadır. ${ }^{19}$

Tazminat; çatışma süreçlerinde zarar gören toplum kesimlerinin zararlarının tazminini ifade etmekte ve onarıcı bir yaklaşımın ürünü olarak değerlendirilmektedir. Bu onarım yalnızca mali ödemeleri kapsamamakta, aynı zamanda özür dileme veya anma programları gibi sembolik bazı adımların atılmasını da ifade etmektedir. ${ }^{20}$ Af; çatışma sürecinde yer alan silahlı grupların, paramiliterlerin ya da gerillaların silah bırakarak, geri dönüşleri ve toplumla yeniden bütünleşmelerini sağlamayı hedefleyen temel mekanizmadır. Burada yaşanan insan hakları ihlallerinin sorumlularının, belirli şartları yerine getirmeleri durumunda affedilmesi söz konusudur. ${ }^{21}$ Kurumsal reformlar (arınma politikaları); çatışma sonrası süreçte, insan hakları ihlallerine bulaşan devlet kurumlarının yeniden yapılandırılması ve personelinin görevden uzaklaştırılmasını ifade etmektedir. Bu reformlar ağırlıklı olarak polis ve silahlı kuvvetler gibi güvenlik sektörü ile yargı kurumları açısından önem taşımaktadır. ${ }^{22}$

GDA’yı olumlayantanımlarınliberalbirdönüşümüesas aldıklarısöylenebilir. ${ }^{23} A n c a k$ söz konusu bu "dönüşüm iddiasına" karşı çeşitli eleştiriler de mevcuttur. Bunların odağında gelişmişlik ile GDA arasındaki çelişkiler yer almaktadır. Örneğin, GDA'nın sosyal adaletin sağlanması noktasındaki eksikliklerinden yola çıkan Mani, dört çelişkiye vurgu yapmaktadır. Bunlardan ilki, GDA’nın çatışmanın kökeninde yer alan sosyal adaletsizliklere, ayrımcılıklara, dı̧̧lamalara ve eşitsizliklere yeterli ölçüde çözüm üretememesidir. İkinci çelişki, toplumun GDA ile gelişme arasında bir tercihe zorlanmasıdır. GDA tüm kaynak-

17 Bu mahkemelerin yapısına ilişkin ayrıntılı bilgi için bkz. William A. Schabas, The International Criminal Tribunals: The Former Yugoslavia, Rwanda and Sierra Leone, Cambridge University Press, New York, 2006.

18 Gülener, Çatışmacı Bir Geçmişten, s.57.

$19 \mathrm{Bu}$ komisyonların yapısı ve işleyişi hakkında ayrıntılı bilgi için bkz. Priscilla B. Hayner, Unspeakable Truths Transitional Justice and the Challenge of Truth Commissions, Second Edition, Routledge Publishing, New York, 2010.

20 International Center for Transitional Justice, The Elements of Comprehensive Justice Policy, http:// ictj.org/about/transitional-justice (Erişim Tarihi 28 Haziran 2013).

21 Gülener, Catışmaıı Bir Geçmişten, s.63-64. Geçiş dönemlerinde af uygulamaları için ayrıca bkz. Louise Mallinder, Amnesty Human Rights and Political Transitions Bridging the Peace and Justice Divide Studies in International Law, Hart Publishing, Oxford and Portland, Oregon, 2008.

22 International Center for Transitional Justice, "What is Transitional Justice?", http://ictj.org/ sites/d efault/files/ICTJ-Global-Transitional-Justice-2009-English.pdf (Erişim Tarihi 28 Haziran 2013).

23 Bkz. Teitel, Transitional Justice, s.20-28. 
ların seferber edilmesi gereken bir lüks ihtiyaç gibi sunulmakta, adilane bir kalkınma göz ardı edilmektedir. Üçüncü çelişki, GDA sürecinin tüm toplumsal kaynakları sömüren bir savaş ekonomisine yol açmasıdır. Dördüncü ve son çelişki ise geçiş sürecine eşlik eden bir şiddet dalgasının toplumsal grupları kuşatmasıdır. Organize suç örgütlerinin ortaya çıkması ile kadınlar, çocuklar ve yabancılar gibi hassas toplum gruplarına karşı şiddetin artış göstermesi söz konusu çelişkinin birer sonucu olarak değerlendirilebilir. ${ }^{24}$

Yukarıdaki eleştiri ile bağlantılı bir başka eleştiri, GDA'nın mağdur odaklı bir yaklaşımın ürünü olarak ortaya çıkmasına karşın bugüne kadarki uygulamaların daha ziyade seçkinleri merkeze alan süreçlere işaret ettiğini ileri sürmektedir. ${ }^{25}$ Buna göre GDA'ya biçilen öncelikler değişmekte, söylem ile uygulama arasındaki çelişkilerden kaynaklı sorunların toplumun güçsüz kesimleri tarafindan daha fazla hissedilmesine neden olmaktadır.

Katılım olgusunu dikkate alarak GDA'ya karşı eleştirel duruş sergileyen bir diğer kaynak olan feminist kuram ise başta hakikat komisyonları olmak üzere çeşitli GDA mekanizmalarındaki tecrübeleri esas alan bir yaklaşımdan hareket etmektedir. Konuya cinsiyet eşitliği temelinde yaklaşan feminist kuramcılar hem çatışma süreçlerinde kadınların maruz kaldıkları ihlallere dikkat çekmekte, hem de meydana getirilen GDA süreçleri içinde erkek egemen bir dil kullanılmasını eleştirmektedir. ${ }^{26} \mathrm{Bu}$ eleştiriyi dile getirenlerden biri olan Nagy'nin tespiti bu noktada oldukça anlamlıdır. Ona göre GDA'nın dar bir hukuksal bakış içine hapsedilmesi hukuk profesyonellerinin sürece hakim hale gelmesini sağlarken, çatı̧̧madan kaynaklanan yapısal şiddetin ve cinsiyet ayrımcılığının göz ardı edilmesine neden olmaktadır. ${ }^{27}$

Bu aşamada GDA'ya ilişkin temel bir ayrımı ortaya koymakta fayda vardır. GDA geçiş döneminin sonuçlarına odaklanan bir yaklaşım içinde ele alındığında eski rejimin yıkılarak yerine yenisinin kurulmasını ve yeni kurulan rejimin "saflğını" ilan etmesini ifade etmektedir. Bu durum önceki otoriter rejimlerden demokratik bir rejime geçiş aç1sından oldukça yararlıdır. Ancak Hansen’in de ifade ettiği gibi bir geçişin olmadığı, yeni bir rejimin tesis edilmediği ancak silahlı bir çatışmadan kaynaklı yaşanan insan hakları ihlalleri ile hesaplaşılması noktasında çok da geçerli gözükmemektedir. Çünkü böyle bir durumda mevcut rejimin kendisi bir GDA sürecinin başlayıp başlamayacağı hususunda

24 Rama Mani, "Dilemmas of Expanding Transitional Justice, or Forging the Nexus between Transitional Justice and Development", The International Journal of Transitional Justice, Vol. 2, 2008, s. 253-265.

25 Simon Robins, "Transitional Justice as a Elite Discourse: Human Rights Practice Where the Global Meets the Local in Post-conflict Nepal”, Critical Asian Studies, 44:1, 2012, s. 4.

26 Christine Bell ve Catherine O'Rourke, "Does Feminism Need a Theory of Transitional Justice? An Introductory Essay", The International Journal of Transitional Justice, Cilt 1, 2007, s.24-25.

27 Rosemary Nagy, "Transitional Justice as Global Project: Critical Reflections", Third World Quarterly, Vol. 29, No. 2, 2008, s. 286-287. GDA süreci içinde "hukukçular"ın oynadığ1 role ilişkin bir başka değerlendirme için bkz. Patricia Lundy and Mark McGovern, "Communitybased Approaches to Post-Conflict 'Truth-telling': Strengths and Limitations", Shared Space: A Research Journal on Peace, Conflict and Community Relations in Northern Ireland, s. 37-38, http://www.community-relations.org.uk/fs/doc/shared-space-issue-1-d-lundy-mcgovern.pdf (Erişim Tarihi 04 Aralık 2013). 
karar verici konumdadır. ${ }^{28}$ Böylesi bir durum ihlallerle hesaplaşmayı devletin inisiyatifine bırakmaktadır. Bu nedenle özellikle çatışma süreçleri bağlamında ele alındığında GDA'nın, politik bir geçişi sağlamaktan öte, aşağıdaki örneklerde de görülebileceği üzere, çatışma süreci içinde bozulmuş olan barışın ve uzlaşının yeniden tesis edilmesine odaklandığ söylenebilir.

\section{Avrupa Coğrafyası ve Geçiş Dönemi Adaleti}

İkinci Dünya Savaşı ile birlikte ilk kez geçmişte yaşadığı acılarla yüzleşmeye başlayan Avrupa'da, GDA'nın uygulanmasında son dönemde Avrupa Birliği (AB) ve Avrupa Konseyi öncülüğünde atılan çeşitli adımlardan bahsedilebilir. $A B$ açısından oldukça yeni bir kavram olan GDA ${ }^{29}$, Avrupa Konseyi açısından ise daha eski bir geçmişe sahiptir. Konsey, doğrudan GDA kavramını kullanmamakla birlikte, kavram ile yakından ilişkilendirilebilecek olan bazı alanlarda çeşitli adımlar atmıştır. Örneğin Konsey bünyesinde yer alan Parlamenterler Meclisi tarafından 1996 yılında çıkarılan 1096 sayılı "Eski Komünist Totaliter Rejimlerin Parçalanmasına İlişsin Kriterler"30, 2004 tarihli, 1414 sayılı "Balkanlardaki İç Şiddet Olayları ve Silahlı Çatışmalar Sonucunda Yok Sayılan Kişiler”31 ve 2005 yılında çıkarılan 1463 sayılı "Zorla Kaybedilmeler"32 başlıklı kararlar, Konsey'in GDA'nın hayata geçirilmesi doğrultusunda attığı önemli adımların başlıcalarıdır.

Kuşkusuz Konsey tarafından kullanılan GDA kavramına ilişkin yaklaşımın şekillenmesinde, Parlamenterler Meclisi gibi politik yönü ağır basan organlarca alınan kararlar belli ilkelerin oluşturulması anlamında ciddi katkılar sağlayabilir. Ancak GDA'nın bir söylem olmaktan öteye geçerek Avrupa açısından nasıl bir pratik içinde şekilleneceğinde AİHM'nin sağlayacağı yaptırım gücünün belirleyiciliği daha önemli gözükmektedir. Sweeney'in de belirttiği üzere Soğuk Savaş sonrası dönemde Mahkemenin başlıca sorumluluğu olan Orta ve Doğu Avrupa ülkelerindeki demokrasiye geçiş süreçlerini gözlemleme görevi ${ }^{33}$ düşünüldüğünde, bu belirleyicilik kanaatimizce daha da anlamlı hale gelmektedir.

28 Thomas Obel Hansen, "Transitional Justice:Toward a Differentiated Theory", Oregon Review of Intenational Law, Cilt 13, No.1, 2011, s.23.

29 Birlik içinde GDA'ya ilişkin atılan adımlar için bkz. Katy A. Crossley-Frolick, "The European Union and Transitional Justice: Human Rights and Post-Conflict Reconciliation in Europe and Beyond", Contemporary Readings in Law and Social Justice, Cilt 3, No.1, 2011, s.33-57; Laura Davis, The European Union and Transitional Justice, International Center for Transitional Justice and The Initiative for Peacebuilding, 2010.

30 Bkz. Resolution 1096 (1996) on Measures to Dismantle the Heritage of Former Communist Totalitarian Systems, http://assembly.coe.int/main.asp?Link=/documents/adoptedtext/ta96/ eres1096.htm\#1 (Erişim Tarihi 19 Ağustos 2013).

31 Bkz. Resolution 1414 (2004) Persons Unaccounted for as a Result of Armed Conflicts or Internal Violence in the Balkans, http://assembly.coe.int/Main.asp?link=/Documents/AdoptedText/ ta04/ERES1414.htm (Erişim Tarihi 19 Ağustos 2013).

32 Bkz. Resolution 1463 (2005) Enforced Disappearances, http://assembly.coe.int/ Main.asp?link=/ Documents/ AdoptedText/ta05/ERES1463.htm (Erişim Tarihi 19 Ăgustos 2013).

33 James A. Sweeney, "Divergence and Diversity in Post-Communist European Human Rights Case”, Connecticut Journal of Int'l Law, Cilt 21, No.1, 2005-2006, s.15. 


\section{Silahlı Çatışmalarda Yaşanan İnsan Hakları İhlallerinin Gideriminde AİHM'nin Rolü ve Etkisi}

Bugün ulus-üstü insan hakları sistemleri ile ulusal yarg1 yerleri arasındaki başlıca gerilim alanlarından birini, yarg1 yetkisinin hangi sınırlar içinde ulus-üstü yarg1 sistemlerine devredileceği meydana getirmektedir. Söz konusu gerilim ulusal makamların sahip olduğu temsile dayalı demokratik karar alma gücünden kaynaklanmaktadır. Başka bir ifadeyle seçilmiş organların demokratik meşruiyetine duyulması gereken saygı ile ilişkilidir. ${ }^{34} \mathrm{Bu}$ nedenle ulusal yargı yerleri üzerinde bir temyiz merci olmadığını birçok kararında dile getirmiş olan AİHM ile Sözleşmeci devletler arasında "yetki devri" ve "takdir marjı" kavramları çerçevesinde zaman zaman anlaşmazlıklar yaşanmaktadır. Nitekim bu durum, Mahkemenin silahlı çatışma süreçlerine ilişkin yaklaşımında da bir çok kez belirginleşmektedir. Mahkeme, çatışma süreçlerinde çatışmanın içeriğine dair bir pozisyon almaktan özenle kaçınırken, çatışma sırasında tarafların AİHS'den kaynaklı yükümlülüklerini yerine getirip getirmediklerini denetlemektedir. ${ }^{35} \mathrm{Bunu}$, adaletin tesis edilebilmesinin ön şartlarından olan hakikati ortaya çıkarmaya çalışarak (fact-finding) gerçekleştirmektedir. GDA'nın temel bileşenlerinden biri olan hakikate ulaşmak açısından oldukça önemli olan bu aşamanın sonrasında, ortaya çıkan zararın tazmin edilmesi söz konusudur. AİHM hükmettiği maddi-manevi tazminat miktarları ile bunu bir nebze de olsa yerine getirmektedir. Ancak bundan daha da önemlisi, Sözleşmeci taraflara hakikatlerden doğan sorumluluklarının hatırlatılmasıdır.

Mahkeme, GDA kavramının kendisine doğrudan bir atıf yapmamış ancak yukarıda bahsi geçen mekanizmalar ile yakından ilişkilendirilebilecek çeşitli kararlara imza atmıştır. Geçmişte gerçekleştirilen ihlallerin yargılanmas ${ }^{36}$, aflar $^{37}$, tazminat uygulamala$\mathrm{r}^{38}$, kurumsal reformlar (özellikle arınma politikaları) ${ }^{39}$ ile ilgili davalar birçok kez AİHM tarafindan karara bağlanmıştır.

AİHM'nin çatışma süreçlerine ilişkin verdiği kararlar dikkate alındığında, Türkiye'nin 1974 yılında Kıbrıs'ta gerçekleştirdiği askeri harekat sonrasında Güney Kıbrıs Rum Kesimi ile yaşanan sorunlar ${ }^{40}$, Eski Yugoslavya'ya gerçekleştirilen NATO Harekatı ${ }^{41}$,

34 Andrew Legg, The Margin of Appreciation in International Human Rights Law: Deference and Proportionality, Oxford University Press, Oxford, 2012, s.76.

35 Egbert Myjer, "Human Rights Without Peace: The European Court of Human Rights and Conflicts Between High Contracting Parties", Margins of Conflicts: The ECHR and Transitions to and from Armed Conflict, Ed. Antoine Buyse, Intersentia, Antwerp-Cambridge-Portland, 2011, s.32.

36 Örnek bazı AİHM kararları için bkz. Sweeney, Restorative Justice and Transitional Justice, s.321322; Brems, Transitional Justice in the Case, s.286-287.

37 Örnek bazı AİHM kararları için bkz. Sweeney, Ağustos, s.323-325; Brems, ibid., s.291-292.

38 Örnek bazı AİHM kararları için bkz. Sweeney, Ağustos, s.332-335; Brems, Ağustos, s.292-294.

39 Örnek bazı AİHM kararları için bkz. bkz. Brems, Ağustos, s.295-298.

40 Bu konuda ayrıntılı bilgi için bkz. Clement Dodd, The History and Politics of the Cyprus Conflicts, Palgrave Macmillan, London, 2010.

41 Bu konuda ayrıntılı bilgi için bkz. Dana H. Allin, Nato's Balkan Interventions, Oxford University Press, New York, 2002. 
Bosna Savaşı ${ }^{42}, 2003$ y1lında Irak’a yapılan uluslararası müdahale ${ }^{43}$, Türk güvenlik güçleri ile terör örgütü PKK arasındaki çatışmalar, Çeçenistan ile Rusya arasında yaşanan silahlı çatışma ${ }^{44}$, Dağlık Karabağ konusunda Azerbaycan ile Ermenistan arasında yaşanan silahlı çatışma ${ }^{45}$, İkinci Dünya Savaş1 sırasında Katyn'de yaşanan katliam ${ }^{46}$, Rusya ile Gürcistan arasında 2008 yılında yaşanan silahlı çatı̧̧ma ${ }^{47}$, 1990'lı yılların başında Hırvatistan ile Sırpların Kontrolündeki Yugoslavya Halk Ordusu arasında yaşanan silahlı çatışma ${ }^{48} \mathrm{Avru}-$ pa coğrafyasında yaşanan başlıca silahlı çatışma süreçleri olarak öne çıkmaktadır.

$\mathrm{Bu}$ çatı̧̧maların bir kısmı uluslararası nitelik gösterirken, bir kısmı ise uluslararası olmayan çatışma (iç çatı̧̧a) biçiminde değerlendirilebilir. GDA açısından söz konusu çatışmalar ile doğrudan ilişkilendirilebileceklerin daha ziyade iç çatışma niteliği gösterenler olduğu söylenebilir. Çünkü iç çatışmalarda ihlali gerçekleştirenler ile mağdurlar, çatışma sonrası süreçte de birlikte yaşamaya devam etmekte, bu anlamda GDA'nın temel amaçlarından olan ihlallerle hesaplaşılması ve adaletin tesis edilmesi yoluyla barışın sağlanması önem kazanmaktadır. Bu çerçeveden bakıldığında özellikle Türkiye'nin 1974 Kıbrı'a düzenlediği askeri harekat sonrası süreç, Bosna Savaşı, Türk güvenlik güçleri ile terör örgütü PKK arasındaki çatışma ve Çeçenistan'da yaşanan çatışmanın konuyla doğrudan ilgili olduğu söylenebilir.

\section{Türkiye’nin 1974 Kıbrıs'a Düzenlediği Askeri Harekat Sonrası Yapılan Başvurulara İlişkin AİHM Kararları}

1974 yılında Kıbrıs Adasına Türkiye tarafından gerçekleştirilen askeri müdahaleden günümüze Rumlar ve Türkler'den oluşan iki toplumlu bir yapı mevcuttur. Kıbrıs'taki bu mevcut durum aslında diğer bir çok çatı̧̧ma sonrası toplumdan farklı bir nitelik göstermektedir. Çatışma Kıbrıs'ta yaşayan Türkler ile Rumlar arasında başlamış, daha sonra Türkiye bu çatı̧̧maya müdahil olmuştur. Halen de adadaki askeri varlı̆̆ devam etmektedir. Dolayısıyla çatı̧̧manın silahlı bir biçimde olmasa da farklı bir şekilde devam ettiği de söylenebilir. GDA sadece çatışma sonrası hayata geçirilen bir süreç olarak dikkate alındığında Kıbrıs'taki durumu açıklamakta yetersiz kalmaktadır. Ancak mevcut

42 Ayrıntılı bilgi için bkz. Steven L. Burg ve Paul Shoup, The War in Bosnia-Herzegovina: Ethnic Conflict and International Intervention, M. E. Sharpe, New York, 1999.

$43 \mathrm{Bu}$ konuda ayrıntılı bilgi için bkz. Marc Weller, Iraq and the Use of Force in International Law, Oxford University Press, New York, 2010.

44 Bu konuda ayrıntılı bilgi için bkz. John B. Dunlop, Russia Confronts Chechnya Roots of a Separatist Conflict, Cambridge University Press, Cambridge, 1998.

$45 \mathrm{Bu}$ konuda ayrıntılı bilgi için bkz. Heiko Kruger, The Nagorno-Karabakh Conflict: A Legal Analysis, Springer, Heidelberg, 2010.

$46 \mathrm{Bu}$ konuda ayrıntılı bilgi için bkz. George Sanford, Katyn and the Soviet Massacre of 1940: Truth, Justice and Memory, BASEES Routledge Series on Russian and East European Studies, Routledge, New York, 2005. Katyn katliamını GDA açısından ele alan bir çalışma için bkz. Serdar Gülener, "AİHM Bir Geçiş Dönemi Adaleti Mekanizması Olabilir (mi?)", Hukuk Adamları Birliği Dergisi (HUKAB), Şayı 7, 2013, s.24-27.

47 Ayrıntılı bilgi için bkz. Ronald D. Asmus, A Little War That Shook the World, Palgrave-Macmillan, New York, 2010.

48 Bkz. The War in Croatia and Bosnia-Herzegovina, 1991-1995, Ed. Ivo Zanic and Branka Magas, Frank Cass Publishers, New York, 2001. 
durumda tam bir antlaşma sağlanmasa da kalıcı barışın sağlanması yönünde önemli çabaların olduğu da göz ardı edilemez. İşte tam da bu noktada söz konusu barışın tesisinde GDA’nın yöntem ve mekanizmalarının önemli imkânlar sunduğu söylenebilir. Nitekim Uluslararası Geçiş Dönemi Adaleti Merkezinin (ICTJ) de tespitleri bu yöndedir. Merkez ile birlikte Elders, Taribsel Diyalog ve Araştırma Derneği (ADHR) gibi sivil toplum örgütlerinin de desteğiyle iki toplum arasında uzlaşının sağlanması yönünde çeşitli adımların atıldığı görülebilir. ${ }^{49} \mathrm{Bu}$ kapsam içinde GDA süreçlerini yaşamış çeşitli ülke tecrübelerinin paylaşılması, yaşananlara ilişkin hakikatlerin ortaya çıkarılmasına dair toplantıların, çalıştayların ve anma törenlerinin yapılması, belgesel çalışmaları ve eğitim faaliyetlerinin düzenlenmesi söz konusu amaca ulaşmak için kullanılan araçlardır. Böylesi bir arka plandan hareket edildiğinde kanaatimizce AİHM'nin Kıbrıs'taki çatışma sonrasında yapılan başvurulara ilişkin yaklaşım tarzı, adada ulaşılmak istenen uzlaşıya ne ölçüde katkı yapabileceğine 1şık tutabilir.

Konuya ilişkin başlıca davalardan biri olan Kıbrıs v. Türkiye $e^{50}$, çatışma sırasında kaybolan kişiler ve bu kayıpların akrabaları, çatı̧̧ma sırasında yerlerinden edilen kişilerin özel hayatları ve mülkiyetleri, Kuzey Kıbrıs Türk Cumhuriyeti (KKTC) sınırları içinde kalan Kıbrıslı Rumlar ile KKTC'de yaşayan Kıbrıslı Türklerin durumunu önceleyen çok boyutlu bir talepler silsilesi üzerinden şekillenmiştir. Güney Kıbrıs Rum Kesimi kayıp şahısların olduğunu, bunların, ya Türk ordusu veya onun milislerinin kendi yetkisi veya sorumluğu altında ya tutuklandığını ya da gözaltında tutulduklarını belirterek, bu şahısların en son davalı devletin etkili denetimi altındaki bölgelerde görüldüğü" yönünde kanıtlar olduğunu ileri su "rmu "ştu" $r .{ }^{51}$

Mahkeme, yaşam hakkı çerçevesinde yaptığı değerlendirmede davalı devletin bu suçu işleyip işlemediğinden ziyade, böyle bir suçun "etkin bir soruşturmaya" 52 konu edilip edilmediğiyle ilgilenmiş ve davalı devletin kendi sorumluluk alanı içinde kaybolan Rumların akıbetlerinin ne olduğu ve nerede olabilecekleri hususunda etkili bir soruşturmada bulunmadığı gerekçesiyle 2. maddenin ihlal edildiği sonucuna varmıştır. ${ }^{53}$ Başvuruyu "özgürlük ve güvenlik hakkını" düzenleyen 5 . madde açısından değerlendiren Mahkeme, davacı devlet tarafından ileri sürülen; davalı devletin "kendi yetkilileri ve görevlilerince tutuklanan şahısların doğru ve güvenilir kayıtlarını tutmadığ1 veya bu şahısların kaybolma tehlikesine karşı koruyucu önlemler almadığı" iddiasını haklı bulmuş ve 5 . maddenin ihlal edildiğini belirtmiştir. ${ }^{54}$

49 "Cyprus", ICTJ, http://ictj.org/our-work/regions-and-countries/cyprus (Erişim Tarihi 03 Aralık 2013).

50 Bkz. AİHM kararı, Kıbrıs v. Türkiye, No. 25781/94, 10 Mayıs 2001.

51 Ibid, para. 119.

52 Mahkemeye göre etkin bir soruşturma şu unsurları içermelidir: 1. Soruşturmayı yapanlar ve yürütenler bağımsız ve tarafsız olmalıdır, 2. Soruşturma etkili ve yeterli olmalıdır, 3. Hemen başlatılmalı ve makul bir hızla yürütülmelidir, 4. Kamuoyu denetimine açık olmalıdır. Bkz. D. J. Harris, M. O’Boyle, E. P. Bates. C.M. Buckley, Avrupa İnsan Hakları Sözleşmesi Hukuku, Çev. Mehveş Bingöllü Kılcı ve Ulaş Karan, Avrupa Konseyi, Ankara, 2013, s.52-54.

53 AİHM karar1, Kibris v. Türkiye, No. 25781/94, 10 Mayıs 2001., para. 136.

54 Ibid, para. 150. 
Kaybolan kişilerin ailelerinin çektikleri acı ve endişeyi Sözleşme'nin işkence yasağını düzenleyen 3. maddesi çerçevesinde değerlendiren Mahkeme, kaybolan kişiler hakkındaki belirsizliğin beraberinde getirdiği endişe halinin ve bunun karşısında yetkili makamların herhangi bir adım atmamasını, insanlık dışı bir muamele olarak değerlendirerek 3. maddenin de ihlal edildiği sonucuna varmıştır. ${ }^{55}$

Mahkeme, 1974 y1lından önce Kuzey'de yaşayan Rumların topraklarına geri dönmelerine izin verilmemesinin yanı sira burada kalan evlerini ziyaret edememelerinin herhangi bir mevzuat hükmüne dayanmadığını ifade ederek, Sözleşme'nin özel ve aile hayatının korunması hakkını ihlal ettiğini belirtmiştir. ${ }^{56}$ Bu çerçevede daha önce Kuzey Kıbrıs'ta yaşayan Rumların mülkleri üzerinde herhangi tasarrufta bulunamadıklarına, dikkat çeken Mahkeme, Sözleşme’ye ek 1 No'lu Protokolün (P-1) 1. maddesinde düzenlenen mülkiyet hakkının ihlal edildiği sonucuna varmıştır. Ayrıca söz konusu ihlalleri önlemede hukuksal anlamda etkili hiçbir çare sunulamamasından dolayı Sözleşme'nin 13. maddesinde düzenlenen "etkili başvuru hakkının" da ihlal edildiğine hükmetmiştir. ${ }^{57}$

Davanın diğer bir boyutunu, çatışma sürecinde Güney Kıbrıs'a geçmeyip Kuzey'de kalan Rumların haklarına ilişkin ihlal iddiaları oluşturmaktadır. Mahkeme, çatı̧̧ma sürecinde ve sonrasında dolaşım özgürlüğüne getirilen kısıtlamaların kendi köyleri dışında, dini törenlere ve dini hayatın diğer alanlarına katılmalarını engellediği için 9. madde$\operatorname{nin}^{58}$, Rumlar için ilkokullarda okutulmak üzere düzenlenen ders kitaplarına aşırı sansür uygulanması nedeniyle 10 . maddenin ${ }^{59}$, öldükten sonra mallarını Güney'de yaşayan akrabalarına miras olarak birakamamaları nedeniyle $\mathrm{P}-1,1$. maddesinin ${ }^{60}$ ve kendilerine özgü (Rumca) bir ortaöğretim eğitiminden mahrum bırakılmaları nedeniyle P-1, 2. maddesinde düzenlenen eğitim hakkının ihlal edildiğine karar vermiştir. ${ }^{61}$ Bunların yanı sıra, bu bölgede yaşayan Rumların etnik köken, din ve dillerinden dolayı uğradıkları ayrımc1 muamelenin aşağılayıcı muameleye dönüştüğ̈n̈ü, bunun Sözleşme'nin 3. maddesinin ihlali olduğunu ${ }^{62}$, ayrıca özel ve aile hayatına saygı haklarının çiğnenmesi nedeniyle 8. maddenin ${ }^{63}$ ve ihlallerin engellenmesine yönelik etkili hukuk yollarının oluşturulmaması nedeniyle de 13. maddenin ihlal edildiğine karar vermiştir. ${ }^{64}$

Davanın son boyutunu, Kuzey Kıbrıs'ta yaşayan (Çingene toplumu dahil) Türkler'in haklarının ihlal edildiği iddiaları oluşturmuştur. Mahkeme bu iddialar içinden yalnızca çatışma sürecinde işlenme olasıllı̆g yüksek olan suçların başında gelen askeri suçlarda,

55 Ibid, para. 156.

56 Ibid, para. 172-175.

57 Ibid, para. 194.

58 Ibid, para. 245.

59 Ibid, para. 254.

60 Ibid, para. 270.

61 Ibid, para. 280.

62 Ibid, para. 309-311.

63 Ibid, para. 296.

64 Ibid, para. 324. 
sivillerin askeri mahkemelerde yargılanmasının Sözleşme'nin 6. maddesinde düzenlenen "adil yargılanma hakkını" ihlal ettiği sonucuna varmıştır. ${ }^{65}$

Varnava v. Türkiye ${ }^{66}$ kararı AİHM tarafindan Kıbrıs'ta yaşanmış olan çatı̧̧ma sürecine dair başka bir karardır. Karar, çatışmalar sırasında kaybolan Kıbrıslı Rumlara ilişkin olarak açılan bir dava sonucunda verilmiştir. Mahkeme, davalı devletin iddiasının aksine, söz konusu kayıp olaylarının Mahkemenin zaman yönünden yetkisinin başladığı tarihten önce yaşanmış olsa bile 2. madde açısından soruşturma yapma yükümlülüğünü ortadan kaldırmayacağını belirtmiştir. Kaybolan kişilerin kaybolma tarihleri üzerinden otuz yıla yakın bir süre geçmiş olmasına rağmen devletin bunların kaybolmaları ile ilgili soruşturma yapma sorumluluğunun ortadan kalkmadığını belirtmiş ve Sözleşme'nin 2. maddesini ihlal edildiği sonucuna varmıştır.

Mahkeme davanın niteliğini dikkate alarak altı ay kuralını genişletici bir şekilde yorumlayarak çatı̧̧ma süreçlerinin istisnai durumuna atıf yapmıştır. Mahkemeye göre bu davada normal soruşturma prosedürlerinin işletilmesi zordur. Dolayısıyla başvurucularda soruşturmalardan sonuç alınamayacağı, bir ilerleme kaydedilemeyeceği kanaatinin uyandığı tarih olan 1990'ların sonunda başvuruların yapılmasında bir sakınca olmadığını belirtmiştir. AİHM, kayıp yakınlarının yaşadıkları kaygı ve endişeyi 3. maddenin ihlali olarak değerlendirmiş. ayrıca, kayıplardan ikisinin akıbeti hakkında davalı devletin herhangi bir soruşturma yürütmediğini, bu nedenle 5. maddenin ihlal edildiği sonucuna varmıştır.

\section{Bosna Savaşıyla İlgili Başvurulara İlişkin AİHM Kararları}

Bosna Savaşı Eski Yugoslavya’nın dağılmasının ardından yüzbinlerce kişinin hayatını kaybettiği ya da yaralandığı, milyonlarca kişinin ise yerlerinden edildiği bir çatışma süreci olarak ağır insan hakları ihlallerine de kaynaklık etmiştir. Her ne kadar uluslararası toplumun müdahalesi gerçekleşmiş olsa da Bosna Savaşı özü itibarıla aynı topraklar üzerinde yaşayan farklı etnik yapıların (iç) çatışması olarak ortaya çıkmıştır. Bu özelliği nedeniyle de GDA açısından önemli örneklerden birini meydana getirmektedir.

BM bünyesinde 1993 yılında kurulan Eski Yugoslavya Uluslararası Ceza Mahkemesi kendisinden sonra gelen birçok GDA süreci açısından özellikle geçmişle hesaplaşma noktasında oldukça önemli bir mekanizma olmuştur. Mahkeme, 1991 yllından itibaren gerçekleştirilen savaş suçlarını yargılamakla görevlendirilmiştir. ${ }^{67}$ Bunun dışında adalet ve güvenlik sektörünün reforma tabi tutulması, çeşitli yeniden giderim mekanizmasının kurulması ve hakikatlerin araştırılması için hakikat komisyonu koalisyonu (Coalition for regional truth commission-RECOM) gibi yapıların meydana getirilmesi, GDA açısından atılan önemli adımlar olarak değerlendirilebilir. Ancak Bosna açısından da geçmişte ya-

65 Ibid, para. 359.

66 AİHM kararı, Varnava v. Turkey, No. 16064/90, 18 Eylül 2009.

67 Mahkemeye bugüne kadar 161 dosya ulaşmış, bunlardan 136 tanesini sonuçlandırmış, 25 tanesi ise halen derdest durumdadir. Bkz. "Key figures of the cases", http://www.icty.org/sid/24 (Erişim Tarihi 02 Aralık 2013). 
şanan ihlallerin hesabının sorulması noktasında çok da önemli mesafelerin kaydedildiğini söylemek oldukça iyimser bir tespit olacaktır. ${ }^{68}$ Yerel düzeydeki bu aksaklıklar dikkate alındığında çatışma sürecinde yaşanan ihlallere dair AİHM'ye yapılan başvuruların sonuçları, yaşanan ihlallerin açığa çıkarılması ve yeniden kazanımın gerçekleştirilmesi adına önemli bir imkân olarak değerlendirilebilir. Dokic v. Bosna Hersek ${ }^{69}$ davası Mahkemenin çatışma sonrası süreçte yeniden kazandırma rolüne ilişkin önemli örneklerden biridir.

Sırp ordusunda asker olan başvurucu Yugoslavya parçalanmadan önce Saraybosna'da bir daire satın almış ancak Bosna Savaşının başlamasının ardından görev yeri Sırbistan’a taşınınca Saraybosna'dan ayrılmak zorunda kalmıştır. Savaşın sona ermesinin ardından çıkarılan "Konutların Yeniden Kazandırılması Kanunu'ndan” faydalanarak konutunu geri almak istemiş ancak yerel makamlar yabancı bir orduda görev yapıyor olması nedeniyle buna izin vermemiştir. Başvurucu ise bu durumun Sözleşme kapsamında korunan mülkiyet hakkı ve ayrımcılık yasağının ihlali anlamına geldiğini iddia etmiştir.

Mahkeme yaptı̆̆ değerlendirmede, başvurucunun savaş suçu işlediğine dair bir işaretin olmadığının altını çizmiş ve yerel yöneticilerin belirttiğinin aksine dairelerin gerçek ihtiyaç sahiplerine verilmediği yönünde bazı şüphelerin olduğuna da dikkat çekmiştir. Dolayısıyla mülkünün iade edilmemesi sonucunda kendisine tazminat ödenmemesinin veya başka bir konut verilmemesinin mülkiyet hakkına bir müdahale olduğunu belirtmiştir.

Palic v. Bosna Hersek $k^{70}$ davasında başvurucu, Bosna Savaşı sırasında bir yerel güvenlik gücüne komutanlık yapan eşinin, 1995 yılında kaybolduğunu, bir daha kendisinden haber alınamadığını bu nedenle Sözleşme'nin 2., 3. ve 5. maddelerinin ihlal edildiğini iddia etmiştir. Mahkeme öncelikle kabul edilebilirlik kriterlerinden biri olan altı ay kuralı açısından başvuruyu değerlendirmiş, ihlalin devam ettiği davalarda bu kuralın uygulanamayacağının da altını çizmiştir. Başvurucunun iç hukuk yollarını kullanmaya başladığını ancak halen soruşturmanın devam ettiğini, dolayısıyla iç hukuktaki yargılamanın sonucunun beklemesine gerek olmadığını, ortada bir ihlal söz konusu ise bunun devam ediyor olabileceğini bu nedenle başvurunun kabul edilebilir olduğuna karar vermiştir. ${ }^{71}$

Başvurucunun 2. maddeye ilişkin ihlal iddiasını değerlendiren Mahkeme, mevcut soruşturmada başvurucunun eşinin akıbetine ilişkin önemli bir aşama kaydedildiğini, 30.000 kişinin kaybolduğu bir savaşın ardından böylesi bir sonucun ciddi bir başarı olduğunun altını çizmiştir. Soruşturmanın etkinliği noktasında başvurucunun eşinin cesedi bulunana ve kaybolma olayının sorumluları adalet önüne çıkarılana kadar 2. maddenin

68 Bkz. Maurice van der Velden, "Transitional Justice in Bosnia and Herzegovina: Tiny Steps Forward", Effectius,http://effectius.com/yahoo_site_admin/assets/docs/TransitionalJusticein BosniaandHerzegovinatinastepsforward_Maurice_Newsletter9_WDW.301102451.pdf (Erişim Tarihi 02 Aralık 2013).

69 AİHM kararı, Dokic v. Bosna Hersek, No. 6518/04, 27 Mayıs 2010.

70 AİHM kararı, Palić v. Bosna Hersek, No. 4704/04, 15 Şubat 2011.

71 Ibid, para. 48-52. 
prosedürel gereklerinin tamamlanamayacağına dikkat çekmiştir. ${ }^{72}$ Sonuç olarak 2. maddeye dayalı bir ihlalin olmadığı sonucuna varmıştır. Mahkeme, ulusal otoritelerin başvurucunun eşini kayıp bir savaş mağduru olarak kabul ettiklerini ve buna ilişkin bir tazminat ödediklerini, dolayısıyla böylesi bir davranışın başvurucuya dönük bir insanlık dışı davranı̧̧ olarak kabul edilemeyeceğini, belirterek 3. maddeden de ihlal bulmamıştır. ${ }^{73}$

Šimšic v. Bosna Hersek $k^{74}$ davasında başvurucu, Nisan-Temmuz 1992 tarihleri arasında Boşnak sivil nüfusa yönelik gerçekleştirilen siyasi, etnik, kültürel ve dini saldırılara, işkencelere ve zorla kaybedilmelere yardım ve yataklık etmekten yargılanarak Bosna mahkemeleri tarafından suçlu bulunmuştur. Başvurucu, 1992-95 tarihleri arasında ulusal hukukun insanlığa karşı işlenen suçlara ilişkin bir düzenleme barındırmadığını, dolayısıyla bu suçtan yargılanmış olmasının Sözleşme'nin "kanunsuz ceza olmaz" başl1ğını düzenleyen 7. maddesine aykırı olduğunu iddia etmiştir. Ardından kendisine temyiz imkanı tanınmaması nedeniyle Sözleşme'ye ek 7 No’lu Protokolün 2. maddesinde düzenlenen "cezai konularda iki dereceli yargılanma hakkının" ihlal edildiğini, ayrıca davasına bakması gereken mahkeme dışında bir mahkeme tarafından yargılandığını, farklı bir uygulamaya maruz kaldığını, bunun da Sözleşme'ye ek 12 No'lu Protokol'ün 1. maddesindeki "ayrımcılığın genel olarak yasaklanması" ilkesine aykırı olduğunu iddia etmiştir. ${ }^{75}$

Mahkeme, başvurucunun belirttiği birinci iddiayı değerlendirirken suça ilişkin davranışın ortaya çıktığ1 tarihte ulusal kanunlarda insanlığa karşı işlenen suçlara ilişkin bir düzenleme olmadığını, bu suçun 2003 yılında Ceza Kanunu'na eklenerek yerel hukuktaki yerini aldığını fakat aynı tarihte uluslararası hukukun çeşitli belgelerinde böyle bir suçtan bahsedildiğinin altını çizmiştir. Zaten ulusal mahkemenin de, söz konusu olaylar incelendiğinde insanlığa karşı işlenen bir suçta olması gereken tüm unsurların mevcudiyetine işaret ettiğini belirtmiştir. Ayrıca başvurucunun bir polis memuru olduğu dikkate alındığında, yaptığı davranışların nelere yol açabileceğinin farkında olması ve bunların cezai olarak sorumluluk doğurabileceğini hesaba katması gerektiğinin altını çizmiştir. Bu nedenle Sözleşme'nin 7. maddesi açısından başvurucunun suçu işlediği tarihte söz konusu davranışının uluslararası hukuk açısından bir suç olduğunu dikkate alarak, başvuruyu açıkça dayanaktan yoksun bulmuş ve reddetmiştir. ${ }^{76}$

Başvurucunun Sözleşme'ye ek 7 No.'lu Protokol'ün 2. maddesine aykırılık iddiasını da değerlendiren Mahkeme, buna ilişkin herhangi bir ihlalin söz konusu olmadığını belirtmiştir. Sözleşme'ye ek 12 No.'lu Protokolü’nün 1. maddesinde yer alan genel ayrımcılık yasağının ihlaline ilişkin iddiayı ise "davanın karmaşıklı̆̆ı ve hassasiyetine" vurgu yaparak açıkça dayanaktan yoksunluk nedeniyle kabul edilebilir bulmamıştır. ${ }^{77}$

$\overline{72 \text { Ibid, para. } 61-71}$

73 Ibid, para. 72-76.

74 AİHM kararı, Šimšić v. Bosna Hersek, No. 51552/10, 10 Nisan 2012.

75 Ibid, para. 20.

76 Ibid, para. 22-24.

77 Ibid, para. 29-32. 
Bosna Savaşına ilişkin yakın tarihli bir karar olan Maktouf ve Damjanović v. Bosna Hersek $^{78}$ kararı, Mahkemenin Šimšić kararından farklı bir yaklaşım tarzını ortaya koymuştur. Başvurucular, 1992-95 yılları arasında Bosna’da sivillere karşı savaş suçu işlemekle suçlanarak ceza almıştır. Mahkeme Šimšić v. Bosna Hersek davasına yaptı̆̆ı atıfla, başvurucuların işledikleri suçun insanlığa karşı işlenen bir suç değil, bir savaş suçu olduğunu belirtmiş ve bu dava ile Šimšić davası arasındaki farkı vurgulamıştır. ${ }^{79}$ Ardından 1976 tarihli Kanun'un sanıkların lehine olduğunu, 2003 tarihli Kanun'un ise daha ağır cezalar getirdiğini belirterek, 2003 tarihli Kanun'un geriye dönük biçimde uygulanmasının Sözleşme'nin 7. maddesinin ihlali sonucunu doğurduğunu ifade etmiştir. ${ }^{80}$

\section{Türkiye’de Güvenlik Güçleri Tarafindan Terör Örgütü PKK'ya Karşı Yürütülen Askeri Operasyonlarla İlgili Başvurulara İlişkin AİHM Kararları}

Türkiye'de güvenlik güçleri ile PKK (Partiya Karkerên Kurdistan-Kürdistan İşçi Partisi) arasında yaşanan çatışma süreci GDA açısından önemli değerlendirmelere konu edilmektedir. ${ }^{81}$ Söz konusu sürecin genel profili incelendiğinde başvurucuların şikâyetlerinin; orantısız güç kullanımına dayalı ölümler, yaşam hakkının korunamaması, kayıplar, insanlıkdışı muamele, mülkiyet kayıpları ve etkin iç hukuk yollarının kurulamamasına odaklandiğg görülmektedir. ${ }^{82}$

Menteş ve diğgerleri ${ }^{83}$ kararı, köy boşaltma ve mülkiyet hakkının ihlali noktasında AİHM'nin bu çatışmaya dair yaklaşımını büyük ölçüde belirlediği kararlardan biri olarak değerlendirilebilir. Başvurucular, terör örgütüne yardım ettikleri gerekçesiyle jandarma tarafından evlerinin yakıldığını ve köylerinden ayrılmak zorunda bırakıldıklarını iddia ederek AİHM'ye başvurmuşlar ve Sözleşme'nin 3., 5., 6., 8., 13., 14. ve 18. maddelerinin ihlal edildiğini iddia etmişlerdir. Mahkeme öncelikle 8. madde üzerinden bir değerlendirme yapmış, başvurucuların aile hayatlarına ve meskenlerine saygı gösterilmediğ̣i için özel ve aile hayatına sayg 1 hakkını düzenleyen 8 . maddeden ihlal bulmuştur. ${ }^{84}$ Daha sonra 3 . maddeye ilişkin değerlendirmesini yapan Mahkeme, başvurucuların kendilerinin ve çocuklarının barınabilecekleri bir yerden alıkonulmalarının yanı sıra, bundan sonra geçimlerini sağlayabilecekleri bir tarla veya bahçeye de sahip olamadıklarını, bu durumun başvurucular üzerinde travmatik etkiler doğuracağını, dolayısıyla insanlık dışı bir muameleye maruz kaldıkları için 3. maddenin ihlal edildiği sonucuna varmıştır. ${ }^{85}$ 5. maddeyle ilgili

78 AİHM kararı, Maktouf and Damjanović v. Bosna Hersek, No. 2312/08 ve 34179/08, 18 Temmuz 2013.

79 Bkz. "Court of Bosnia and Herzegovina should not have retroactively applied the 2003 Criminal Code to two war criminals", ECHR Press Release issued by the Registrar of the Court, 18 Temmuz 2013, s.3.

80 Ibid, s. 3-4.

81 Bu değerlendirmeler için bkz. Gülener, Çatışmaıı Bir Geçmişten, s.44, 1 no'lu dipnot.

82 Bkz. ECHR Press Unit, Armed Conflict Factsheet, s. 3.

83 AİHM Kararı, Menteş ve diğgerleri v. Türkiye, No. 58/1996/677/867, 28 Kasım 1997.

84 Ibid, para. 73 .

85 Ibid, para. 76. 
şikâyete ilişkin değerlendirmede, kişilerin evlerinin olmamasından kaynaklı güvensizliğin özgürlük ve güvenlik hakkını düzenleyen 5. madde kapsamında ele alınamayacağını belirterek kabul etmemiştir. ${ }^{86} 6$. maddeye ilişkin iddianın aslen 13. madde kapsamında değerlendirilmesi gerektiğini belirten Mahkeme, başvuruculara uğradıkları ihlal nedeniyle etkin bir yargı yolu oluşturulmaması nedeniyle 13. maddenin ihlaline hükmetmiştir. ${ }^{87}$

Orhan v. Türkiye $e^{88}$ kararı, bu çatı̧̧ma sürecinde ortaya çıkan bir diğer temel ihlal alanlarından olan "gözaltındayken kaybedilmeler" ile ilgilidir. Başvurucu, 1994 yılında yaşadığg köyün yakılıp-yıkıldığını, daha sonra aralarında kendi kardeşlerinin de olduğu kişilerin zorla götürüldügünü ve bir daha kendilerinden haber alınamadığını belirterek Mahkemeye başvurmuştur.

Mahkeme 2. madde kapsamında yaptığı değerlendirmede, o dönemde olayın yaşandığı bölgenin koşulları da dikkate alındığında kaybolan bu kişilerin zorla bilinmeyen bir yere götürülmelerinin Türk otoritelerinin sorumluluğunda olduğunu belirtmiş, söz konusu dönemde olayın yaşandığı yerdeki güvenlik güçlerinin hesap verebilirliklerini sağlamaya dönük soruşturmaların etkin bir biçimde yürütülmesi hususunda çeşitli engellerin olduğunu ifade etmiştir. Dolayısıyla zorla kaybedilmelerinin üzeriden 8 yıla yakın bir sürenin geçmiş olması ve o kişilerden bir daha haber alınamaması o kişilerin öldüğü hususunda Mahkemede güçlü bir kanaatin oluşmasını sağlamıştır. Bu nedenle AİHM, çeşitli zamanlarda olayın aydınlatılması ile ilgili soruşturmalar açılmış olsa da, bunlarda yaşanan eksiklikleri de işaret ederek 2. maddenin ihlal edildiği sonucuna varmışır. ${ }^{89} 5$. maddeye dönük olarak da ihlal bulan Mahkemenin buna ilişkin temel gerekçesi gözaltının nedeninin açıklanamaması ve temel hukuki güvencelerden tamamen yoksun olmasıdır. ${ }^{90}$ Köyün boşaltılması evlerin yakılmasının ağır bir ihlal olduğunu dile getiren Mahkeme, bu durumun aile ve özel hayata saygı hakkı ile mülkiyet hakkını da ortadan kaldıran bir nitelik gösterdiğine işaret ederek, Sözleşme'nin 8. maddesi ile P-1,1'in de ihlal edildiği sonucuna varmıştır. ${ }^{91}$ Söz konusu ihlal nedenlerine dayalı olarak etkin bir yarg1 yolu oluşturulamadığı gerekçesiyle 13. maddenin, ayrıca başvurucunun AİHM'ye yaptığ 1 başvuruya ilişkin olarak Savcilığa çağrılmış olmasının bireysel başvuruyu engellemeye dönük bir davranı̧̧ sayıldığını belirterek 34. maddenin ihlaline hükmetmiştir. ${ }^{92}$

Benzer ve diğerleri v. Türkiye ${ }^{93}$, yakın bir zaman önce verilen önemli kararlardan biridir. Başvurucular, 1994 yılında PKK ile mücadelede güvenlik güçleriyle ortak hareket etmedikleri için savaş uçakları tarafından köylerinin bombalandığını, çok sayıda kişinin öldürüldüğünü ve yaralandığını ayrıca mülklerinin yok edildiğini, dolayısıyla Sözleşme'nin 2., 3. ve 38. maddelerinin ihlal edildiğini ileri sürmüşlerdir.

86 Ibid, para. 79.

87 Ibid, para. 92.

88 AİHM Kararı, Orhan v. Türkiye No. 25656/94, 18 Haziran 2002.

89 Ibid, para. 328-349.

90 Ibid, para. 374.

91 Ibid, para. 379.

92 Ibid, para. 401-411.

93 Bkz. AİHM Kararı, Benzer ve diğerleri v. Türkiye, No. 23502/06, 12 Kasım 2013. 
AİHM, başvuruyla ilgili kararında Sözleşme'nin 2. maddesinin hem devletin ö1dürmeme yükümlülüğü açısından hem de etkin soruşturma yapmaması açısından ihlal bulmuştur. 3. maddeyle ilgili değerlendirmesinde de köylülerin, akrabalarının ölümüne ve evlerinin tamamen yıkılmasına tanıklık etmek zorunda bırakıldıklarını bu nedenle 3 . maddenin de ihlal edildiğini belirtmiştir. Ayrıca Türkiye'nin söz konusu olayın yaşandığı sıradaki uçuş kayıtlarını vermediği ve mahkemeye eksik belge teslim ettiği için de 38 . maddenin ihlal edildiği sonucuna varmış ve başvuruculara tazminat ödenmesine karar vermiştir. Türkiye açısından karara ilişkin en çarpıcı nokta, köy bombalanmasının sorumlularının kimliklerini tespit etmek ve cezalandırma amacıyla dosyanın soruşturulmasının "kaçınılmaz" olduğu sonucuna varılmış olmasıdır. ${ }^{94}$

\section{Çeçenistan'da Yaşanan Çatışmalara İliş̧kin Başvurularla İlgili AIHM Kararları}

1990’lı yıllardan itibaren Rus ordusu ile Çeçenler arasında yaşanan çatışmalar ciddi insan hakları ihlallerine yol açması nedeniyle GDA’nın uygulanabilirliği kapsamında değerlendirilebilecek bir diğer silahlı çatışma sürecidir. Tarafların oldukça kompleks bir yapı sergilediği bu çatışmada düzenli bir ordu karşısında gerilla taktiği ile savaşan bir grup olması, bu grubun da kendi içinde alt gruplara bölünmüş olması, çatışmayı bir iç savaş niteliğine büründürmektedir. ${ }^{95}$ Söz konusu karmaşık yapının varlığının GDA’nın uygulanabilirliği açısından da önemli sorunların ortaya çıkmasına zemin hazırladığ 1 ifade edilebilir. Özellikle ihlallere karışan tarafların tespiti ve bunların hesap verebilirliklerinin sağlanması noktasinda bu durum daha da belirgindir.

Çeçenistan'da yaşanan bu çatışmanın AİHM'ye ilk yansımaları 2005 yılından itibaren yapılan başvurulardan izlenebilmektedir. Bu çerçevede söz konusu çatışmaya dair başvurulardan 230 tanesinde ihlal bulunurken halen 350 dava derdest gözükmektedir. Başvuruların yüzde 60'nın konusunu zorla kaybedilmeler oluştururken geriye kalan yüzde 40 ' 1 ise sivil ölümleri ve yaralanmaları, ev boşaltmalar, mayınlar, hukuksuz tutuklamalar ile işkence ve kötü muameleler meydana getirmektedir. ${ }^{96} \mathrm{Bu}$ çerçevede Sözleşme'nin 2., 3., 5., 8., 13., 14. maddeleri ile P-1, 1. maddesinin başvurularda en fazla kullanılan maddeler olduğu görülmektedir. ${ }^{97}$

Bu davaların başlicalarından olan Isayeva, Yusupova ve Bazayeva v. Russia ${ }^{98}$ ile $I_{s-}$ yeva v. Rusya99, aynı zamanda AİHM'nin Sözleşme ile insancıl hukuk arasındaki ilişkiyi

94 Emma Sinclair-Webb, "AİHM’in Kuşkonar Kararı, Mücadelede Dönüm Noktası”, Bianet, 15 Kasım 2013, http://www.bianet.org/bianet/insan-haklari/151344-aihm-in-kuskonar-kararimucadelede-donum-noktasi (Erişim Tarihi 02 Aralık 2013).

95 Benzer yöndeki değerlendirmeler için bkz. Dmitriy Piskunov, Transitional Justice Prospects for Chechnya, Riga Graduate School of Law, 2013, s.18.

96 Söz konusu istatistikler için bkz. ECHR Press Unit, Armed Conflict Factsheet, s. 6-7.

97 Ibid, s. 7.

98 AİHM Karar1, Isayeva, Yusupova ve Bazayeva v. Rusya, No. 57947/00, 57948/00 ve 57949/00, 24 Şubat 2005.

99 AİHM Kararı, Isayeva v. Rusya, No. 57950/00, 24 Şubat 2005. 
nereye konumlandırdığı ile ilgili önemli veriler sunmaktadır. Mahkeme, bu kararında ilk kez çatışma süreçlerinde Sözleşmeci devletlerin sadece Sözleşmeyi değil, insancil hukuku da gözeterek hareket etmeleri gerektiğini vurgulamıştır. ${ }^{100}$ Her iki dava da, Rus uçaklarının yaptıkları bombalama sırasında ölen sivillerle ilgilidir.

Mahkeme birinci davaya ilişkin yaptığı değerlendirmede, gerçekleştirilen bombalamanın meşru amaçlar gütmüş olsa bile insan hayatına en az zararı verecek biçimde planlanması gerektiğini, oysa mevcut olayda orantısız bir biçimde kuvvet kullanıldı̆̆ını bu nedenle Sözleşme'nin yaşam hakkını düzenleyen maddesinin esas yönünden ihlal edildiğini belirtmiştir. Ayrıca olayın etkin bir biçimde soruşturulmadığını, sorumluların tespitinde ve görgü tanıklarının dinlenilmesinde gecikmeler olduğunu belirterek aynı maddenin usuli olarak da ihlal edildiğini tespit etmiştir. Olayda yakınlarını kaybeden başvurucunun yaşadığı ağır kayıp ve acıdan dolayı işkence yasağını düzenleyen 3. maddenin, başvurucuların başvurabilecekleri etkin bir yarg1 yolu sunulmaması nedeniyle 13. maddenin ve mülklerin zarar görmesi nedeniyle de mülkiyet hakkını düzenleyen P-1, 1. maddesinin ihlal edildiğine ve başvuruculara tazminat ödenmesine hükmetmiştir.

Isayeva v. Rusya kararında da AİHM, Sözleşme'nin 2. maddesinin devlete yüklediği öldürmeme yükümlülüğünün ihlal edildiğini ayrıca ölümlerle ilişkili olarak ihlallerden sorumlu olanların hesap verebilirliğinin sağlanması adına etkin bir soruşturma yürütülmediği için aynı maddenin usuli yönden de ihlal edildiğini ifade etmiştir. Mahkemenin bir önceki davada olduğu gibi burada da devletin gerektiğinde güç kullanma yetkisini kullanabileceğini belirtmiş, ancak bunun ölçüsüz olmaması gerektiğinin altını çizmiştir. Ayrıca benzer iddialarla açılmış olan Khashiyev ve Akayeva v. Rusya ${ }^{101}$ davası da yine aynı gerekçelerle ihlal kararları ile sonuçlanmıştır.

AİHM'nin Çeçenistan'daki çatışmalara ilişkin verdiği kararlarda dikkat çeken bir diğer husus, devletin gerçeklerin açığa çıkması için ne ölçüde gayret göstermesi gerektiğidir. Musayev ve diğgerleri v. Rusya kararında ${ }^{102}$, AİHM, 2. maddeye ilişkin usuli yönden verdiğ i ihlal kararında Rus makamlarından soruşturmayla ilgili belgeler istenildiğinde önce bunları vermedikleri daha sonra ise eksik olarak gönderdikleri için 2. maddenin usuli olarak ihlal edildiği sonucuna varmıştır. Çeçenistan ile Rusya arasındaki çatı̧̧mada insan haklarına ilişkin başlıca sorun alanlarından bir diğeri zorla kaybedilmelerdir. AİHM, özellikle güvenlik güçleri tarafından tutuklu iken kaybedilenlerin, Rusya açısından sistematik bir sorun teşkil ettiğini ve gerekli önlemlerin alınması gerektiğini zaman zaman vurgulamaktadır. ${ }^{103}$

100 Abresch, "A Human Rights Law of the Internal Armed Conflict", s.741.

101 AİHM Kararı, Khashiyev ve Akayeva v. Rusya No. 57942/00 ve 57945/00, 24 Şubat 2005.

102 Örneğin bkz. AİHM Kararı, Musayev ve diğerleri v. Rusya, No. 57941/00, 58699/00 ve 60403/00, 26 Temmuz 2007; AİHM kararı, Tashukhadzhiyev v. Rusya, No. 33251/04, 25 Ekim 2011.

103 Bkz. AİHM karar1, Tuluyeva v. Rusya, No. 63638/09, 20 Haziran 2013. 


\section{Sonuç ve Değerlendirme}

GDA'nın tesis edilmesinde yerel unsurların başarı düzeyleri uluslararası aktörlerin ve kurumların bu süreçler üzerindeki etkisi üzerinde de belirleyicidir. ${ }^{104}$ Söz konusu etkiye sahip olma potansiyeli en yüksek aktörlerin başında ise AİHM gelmektedir. Mahkemenin çatı̧̧ma süreçlerine ilişkin kararlarına bakıldığında üç temel etkisinin ${ }^{105}$ olduğu görülebilir. Söz konusu kararlar incelendiğinde Sözleşme'nin 2. ve 3. maddesine dayalı olarak verdiği ihlallerin ağırlığı dikkat çekmektedir. Bunlarla birlikte 5., 7., 13. ve P1-1. maddesine dayalı ihlal kararları da söz konusudur. Özellikle yaşam hakkının ve işkence yasağının çatışma süreçlerinde yaşanan insan hakları ihlallerinin başlıcaları olduğu görülmektedir. Mahkeme bu maddelere dayalı olarak sunduğu gerekçelerde, sıklıkla Sözleşmeci devletlere yüklediği usuli yükümlülüğe atıf yapmaktadır.

2. madde çerçevesinde "etkin soruşturma yapmamak" devletler tarafindan gerçekleştirilen temel bir ihlal nedenidir. AİHM, etkin soruşturma yapma görevini Sözleşmeci devletin üstlenmesi gereken pozitif bir yükümlülük ${ }^{106}$ biçiminde değerlendirmektedir. Bu çerçevede verdiği ihlal kararları ile ulusal makamların hesap verebilirliğini gündeme getirerek, yapılan yargılamalardaki boşlukları doldurucu bir işlev görmektedir.

3. madde açısından ortaya çıkan ihlallere bakıldığında ağırlıklı olarak çatışma süreçlerinde zarar görenlerin (özellikle zorla kaybedilme olaylarında) yakınlarının yaşadıkları acı ve endişe haline vurgunun ağırlıklı olduğu görülmektedir. Mahkeme Sözleşmeci devletin bu tip durumlarda insanlıkdışı muamele yaptığına hükmederek bu maddeyi GDA'nın onarıcilık boyutuyla ilişkilendirilebilecek bir biçimde kullanmakta ve çatışma süreçlerinin toplumsal anlamdaki yıkıcılığına işaret etmektedir. 5. madde kapsamındaki ihlaller, devletin gözetimi ve kontrolü altında kaybolan kişilere ilişkin başvurularda söz konusudur. Yine zorla kaybedilme başvurularında kullanılan bu madde Sözleşmeci devletin resmi görevlilerinin hesap verebilirliklerine gönderme yapmaktadır. Sözleşme'nin

104 Naomi Roth Arriaza, “The Role of International Actors in National Accountability Processes”, The Politics of Memory: The Transitional Justice in Democratizing Societies, Ed. Alexandra Barahona de Brito Carmen González-Enríquez and Paloma Aguilar, Oxford University Press, New York, 2001, s. 40.

105 Buyse ve Hamilton çatışma süreçlerinde AİHM'in üç farklı etkide bulunabileceğine işaret etmektedir. Bunlardan ilki insan hakları ihlallerine ilişkin yargılamanın doğrudan AİHM tarafından yapılması ve sonuçlarının ulusal makamlar tarafindan yerine getirilmesidir. Özellikle mağdurlara tazminat ödenmesine dair kararlar buna örnek olarak verilebilir. İkinci etki daha dolaylıdır. Burada, ulusal makamların geçiş süreci içindeki çabalarına destek verilmesi veya yargılamaya ilişkin boşlukların doldurulması söz konusudur. Üçüncü ve diğerlerine göre daha sembolik olan etki ise toplumsal hafızanın canlı tutulmasını sağlamaktır. Görüldügüü üzere her üç etki de, AİHM'nin GDA süreçlerinde diğer yöntem veya araçlardan daha geniş ve kapsayıcı roller üstlenebileceğine işaret etmektedir. Antoine Buyse ve Michael Hamilton, "Conclusions", Transitional Jurisprudence and the European Convention on Human Rights, Ed. Antoine Buyse ve Michael Hamilton, Cambridge University Press, Cambridge, 2011, s.293-296.

106 AİHM'in pozitif yükümlülük kavramına ilişkin yaklaşımı ve örnek kararları için bkz. Yüksel Metin, “Avrupa İnsan Hakları Sözleşmesinin Yaşamın ve Sağlığın Korunması ile İlgili Olarak Taraf Devletlere Yüklediği Pozitif Yükümlülükler”, Uluslararası İlişkiler, Cilt 7, Sayı 27, Güz2010, s.111-132. 
"kanunsuz suç ve ceza olmaz" başlığını düzenleyen 7. maddesi ise özellikle insanlığga karşı işlenen suçlarda kullanılmaktadır. Bu maddenin kullanımında Mahkeme, insan hakları hukukunun ötesine geçerek, uluslararası insancıl hukukun alanına girmekte ${ }^{107}$ ulusal makamların Sözleşme çerçevesindeki eksikliklerine dikkat çekmektedir.

AİHM, "etkili bir iç hukuk yoluna başvurma hakkını" düzenleyen 13. maddeyi "bağl1-ilişkili bir madde" olarak kullanmaktadır. Başka bir ifadeyle 2., 3. ve 5. maddeye dair bulduğu usuli ihlallerde (etkili bir soruşturma yapılmaması gibi) 13. maddeden de sıklıkla ihlal bulmaktadır. Dolayısıyla ulusal yargılamaların yetersizliğine dikkat çeken ana maddelerin başında 13. madde gelmektedir. AİHM'nin Sözleşme’nin 38. maddesine ilişkin yaklaşımı, silahlı çatışma süreçlerinde devletin ihlallerinin ortaya çıkması hususunda göstereceği iradeye etki etmesi açısından önemlidir. Mahkemenin çelişmeli yarg1lama ilkesine uygun olarak inceleme yapma yetkisini kullanabilmesi için devletlerin her türlü kolaylığ1 gösterme yükümlülüğünü gündeme getiren bu madde, özellikle AİHM tarafından ihlallere ilişkin hakikatlere ulaşılmasında devletleri zorlayıcı bir etkiye sahiptir. Nitekim Mahkeme zaman zaman işbirliğinden kaçınan devletleri, bu maddeden mahkum etmektedir.

Mahkeme, çatışma süreçlerinde P-1, 1. madde kapsamında mülke erişememe ve mülklerden etkin bir şekilde yararlanamama ve bunlar sonucunda da herhangi bir tazminat ödenmemesi durumlarında ihlale hükmetmiştir. Dolayısıyla P-1, 1. maddesi mağdurlar üzerinde onarıcı ve yeniden kazandırıcı etki sağlayan başlıca maddelerden bir diğeridir.

İkinci Dünya Savaşı'nın meydana getirdiği yıkımın bir ürünü olan AİHM, çatışma sonrası Avrupa'da uzlaşının ve barışın sağlanması amacına hizmet eden en önemli aktörlerin başında gelmektedir. Ancak AİHM, ikincillik (subsidiarity) ilkesi gereği Sözleşme’ye taraf olan devletlerin Sözleşme'ye bağlı kalmalarında ulusal makamların sahip olduğu takdir marjına saygı göstermek zorundadır. Bunun önemli yansımaları Mahkemenin çatışma süreçlerine ilişkin yaptı̆̆ı yargılamalarda görmek olasıdır. Mahkemenin GDA'ya ilişkin rolü sürecin doğrudan bir aktörü olmaktan öte, silahlı çatışmanın taraflarının Sözleşme kapsamında hukuka bağlı kalmalarını sağlamak şeklindedir. Bunu gerçekleştirirken öncelikle hakikatlerin ortaya çıkarılmasını hedeflemektedir. Cezai bir adaletin sağlanmasından çok ulusal makamların yaptıkları yargılamalardaki eksiklere işaret eden bu sürecin sonunda, çatışan tarafların barışa ulaşmalarını kolaylaştıracak bir onarıma katkıda bulunulmaktadir. 


\section{Kaynakça}

"12 Ağustos 1949 Tarihli Cenevre Sözleşmeleri ve Ek Protokolleri”, Yay. Haz. Melike Batur Yamaner, A. Emre Öktem, Bleda Kurtdarcan ve Mehmet C. Uzun, Galatasaray Üniversitesi Hukuk Fakültesi Yayınları, http://www.icrc.org/ eng/home/languages/turkish/ files/sozlesmeleri-protokolleri-conventions-protocols.pdf (Erişim Tarihi 26.07.2013).

Allen, Tom, "Restitution and Transitional Justice in the European Court of Human Rights", Columbia Journal of European Law, 13 (1), 2007, s. 1-46.

Allen, Tom, "Transitional Justice and the Right to Property under the European Convention on Human Rights", Stellenbosch Law Review 3", s. 413-430.

Allin, Dana H., Nato's Balkan Interventions, Oxford University Press, New York, 2002.

Arriaza, Naomi Roth, "The Role of International Actors in National Accountability Processes", The Politics of Memory: The Transitional Justice in Democratizing Societies, Ed. Alexandra Barahona de Brito Carmen González-Enríquez and Paloma Aguilar, Oxford University Press, New York, 2001.

Asmus, Ronald D., A Little War That Shook the World, Palgrave-Macmillan, New York, 2010.

Atuahene, Bernadette, Property and transitional Justice, UCLA Law Review, Disc 65, 2010, s. 65-93.

Bell, Christine ve Catherine O'Rourke, "Does Feminism Need a Theory of Transitional Justice? An Introductory Essay", The International Journal of Transitional Justice, Vol. 1, 2007, s. 23-44.

Bickford, Louis, "Transitional Justice?”, The Encyclopedia of Genocide and Crimes Against Humanity, Vol. 3, Macmillian Reference, 2004, s. 1045-1047.

Bouchet-Saulnier, Françoise, İnsancıl Hukuk Sözlüğ̈̈, çev. Selahattin Bağdatlı, İletişim Yayınları, İstanbul, 2002.

Brems, Eva, "Transitional Justice in the Case of the European Court of Human Rights", The International Journal of Transitional Justice, Vo. 5, 2011, s. 282-303.

Burg, Steven L. ve Paul Shoup, The War in Bosnia-Herzegovina: Ethnic Conflict and International Intervention, M. E. Sharpe, New York, 1999.

Buyse, Antoine Christian, Post-conflict Housing Restitution: the European Human Rights Perspective, with a Case Study on Bosnia and Herzigovina, Intersentia, 2008.

Buyse, Antoine ve Michael Hamilton, "Conclusions", Transitional jurisprudence and the European Convention on Human Rights, Ed. Antoine Buyse ve Michael Hamilton, Cambridge University Press, Cambridge, 2011,s .286-300.

Buyse, Antoine, "Home Sweet Home? Restitution in Post-Conflict Bosnia and Herzegovina", Netherlands Quarterly of Human Rights, Vol. 27/1, s. 9-26.

"Court of Bosnia and Herzegovina should not have retroactively applied the 2003 Criminal Code to two war criminals", ECHR Press Release issued by the Registrar of the Court, 18 Temmuz 2013.

"Cyprus", ICTJ, http://ictj.org/our-work/regions-and-countries/cyprus (Erişim Tarihi: 03.12.2013). 
Crossley-Frolick, Katy A., “The European Union and Transitional Justice: Human Rights and Post-Conflict Reconciliation in Europe and Beyond", Contemporary Readings in Law and Social Justice, Vol. 3 (1), 2011, s. 33-57.

Davis, Laura, The European Union and Transitional Justice, International Center for Transitional Justice and The Initiative for Peacebuilding, 2010.

Dodd, Clement The History and Politics of the Cyprus Conflicts, Palgrave Macmillan, London, 2010.

Dunlop, John B., Russia Confronts Chechnya Roots of a Separatist Conflict, Cambridge University Press, Cambridge, 1998.

ECHR Press Unit, Armed Conflict Factsheet, http://www.echr.coe.int/ Documents/FS_Armed_conflicts_ENG.pdf (Erişim Tarihi: 28.07.2013).

Elster, Jon, Closing the Books: Transitional Justice in Historical Perspective, Cambridge University Press, New York, 2004.

Guidance Note of the Secrateray General, United Nations Approach to Transitional Justice, 2010, s. 2, http://www.unrol.org/files/TJ_Guidance_Note_March_2010FINAL.pdf (Erişim Tarihi: 28.07.2013).

Gülener, Serdar, "AİHM Bir Geçiş Dönemi Adaleti Mekanizması Olabilir (mi?)”, Hukuk Adamları Birliği Dergisi (HUKAB), Sayı: 7, 2013, s. 24-27.

Gülener, Serdar, "Çatışmacı bir Geçmişten Uzlaşmacı Bir geleceğe Geçişte Adalet Arayış1: Geçiş Dönemi Adaleti ve Mekanizmalarına Genel Bir Bakış”, Uluslararası Hukuk ve Politika, USAK Yayınları, Cilt 8, Sayı 32, s. 43-76.

Hansen, Thomas Obel, “Transitional Justice: Toward a Differentiated Theory”, Oregon Review of Intenational Law, Vol. 13,1, 2011, s. 1-46.

Harris, D. J., M. O’Boyle, E. P. Bates, C.M. Buckley, Avrupa İnsan Hakları Sözleşmesi Hukuku, Çev. Mehveş Bingöllü Kılcı ve Ulaş Karan, Avrupa Konseyi, Ankara, 2013.

Hayner, Priscilla B., Unspeakable Trutbs Transitional Justice and the Challenge of Truth Commissions, Second Edition, Routledge Publishing, New York, 2010.

International Center for Transitional Justice, The Elements of Comprehensive Justice Policy, http://ictj.org/about/transitional-justice (Erişim Tarihi: 28.06.2013).

"Key figures of the cases", http://www.icty.org/sid/24 (Erişim Tarihi: 02.12.2013).

Kritz, Neil J., Transitional Justice: How Emerging Democracies Reckon with Former Regimes, Vol. 1-2-3, , United States Institute of Peace, 1995.

Kruger Heiko, The Nagorno-Karabakb Conflict: A Legal Analysis, Springer, Heidelberg, 2010.

Legg, Andrew, The Margin of Appreciation in International Human Rights Law: Deference and Proportionality, Oxford University Press, Oxford, 2012.

Lundy, Patricia ve Mark McGovern, "Community-based Approaches toPost-Conflict 'Truthtelling': Strengths and Limitations", Shared Space: A Research Journal on Peace, Conflict and Community Relations in Northern Ireland, s. 37-38, http://www.communityrelations.org.uk/fs/doc/shared-space-issue-1-d-lundy-mcgovern.pdf (Erişim Tarihi: 04.12.2013). 
Mallinder, Louise, Amnesty Human Rights and Political Transitions Bridging the Peace and Justice Divide Studies in International Law, Hart Publishing, Oxford and Portland, Oregon, 2008.

Mani, Rama, "Dilemmas of Expanding Transitional Justice, or Forging the Nexus Between Transitional Justice and Development", The International Journal of Transitional Justice, Vol. 2, 2008, 253-265.

Metin, Yüksel, “Avrupa İnsan Hakları Sözleşmesinin Yaşamın ve Sağlığın Korunması ile İlgili Olarak Taraf Devletlere Yüklediği Pozitif Yükümlülükler, Uluslararası İlişkiler, C. 7, Say1 27, Güz-2010, s. 111-132.

Mrázek, Josef, "Armed Conflicts and Use of Force", Czech Yearbook of Public E Private International Law, 2010/1, s. 87-109.

Myjer, Egbert, "Human Rights Without Peace: The European Court of Human Rights and Conflicts Between High Contracting Parties", Margins of Conflicts: The ECHR and Transitions to and from Armed Conflict, Ed. Antoine Buyse, Intersentia, AntwerpCambridge-Portland, 2011, s. 1-34.

Nagy, Rosemary, “Transitional Justice as Global Project: Critical Reflections”, Third World Quarterly, Vol. 29, No. 2, 2008, s. 275-289.

Office of the United Nations High Commisioner for Human Rights, Rule of Law Tools of Post Conflict States: Prosecution Initiatives, New York and Geneva, 2006.

Piskunov, Dmitriy, Transitional Justice Prospects for Chechnya, Riga Graduate School of Law, 2013.

Robins, Simon, “Transitional Justice as a Elite Discourse: Human Rights Practice Where the Global Meets the Local in Post-conflict Nepal”, Critical Asian Studies, 44:1, 2012, s. 303-330.

"Resolution 1096 (1996) on Measures to Dismantle the Heritage of Former Communist Totalitarian Systems", http://assembly.coe.int/main.asp?Link=/ documents/adoptedtext/ ta96/eres1096.htm\#1 (Erişim Tarihi: 19.08.2013).

"Resolution 1414 (2004) Persons Unaccounted for as a Result of Armed Conflicts or Internal Violence in the Balkans", http://assembly.coe.int/Main.asp?link=/ Documents/AdoptedText/ta04/ERES1414.htm (Erişim Tarihi: 19.08.2013).

“Resolution 1463 (2005) Enforced Disappearances”, http://assembly.coe.int/ Main.asp?link= /Documents/AdoptedText/ta05/ERES1463.htm Erişim Tarihi: 19.08.2013).Sanford, George, Katyn and the Soviet Massacre of 1940: Truth, Justice and Memory, BASEES Routledge Series on Russian and East European Studies, Routledge, New York, 2005.

Schabas, William A., The International Criminal Tribunals: The Former Yugoslavia, Rwanda and Sierra Leone, Cambridge University Press, New York, 2006.

Sweeney, James A., "Divergence and Diversity in Post Communist European Human Rights Case”, Connecticut Journal of Int'l Law, Vol. 21:1, 2005-2006, s. 1-40.

Sweeney, James A., "Restorative Justice and Transitional Justice at the ECHR", International Criminal Law Review, (12), 2012, s. 313-337.

Teitel, Ruti G., Transitional Justice, Oxford University Press, New York, 2000. 
The War in Croatia and Bosnia-Herzegovina, 1991-1995, Ed. Ivo Zanic and Branka Magas, Frank Cass Publishers, New York, 2001.

United Nations Human Rights Office of the High Commissioner, International Legal Protection of the Human Rights in Armed Conflict, New York and Geneva, 2011.

Velden,Maurice van der, "Transitional Justice in Bosnia and Herzegovina: tiny steps forward", Effectius, http://effectius.com/yahoo_site_admin/assets/docs/TransitionalJusticeinBosniaandHerzegovinatinastepsforward_Maurice_Newsletter9_WDW.301102451. pdf (Erişim Tarihi: 02.12.2013).

Vite, Sylvain,Typology Of Armed Conflicts In International Humanitarian Law: Legal Concepts And Actual Situtuations, International Review of the Red Cross, Volume 91 Number 873 March 2009, s. 70.

Webb, Emma Sinclair, “AİHM'in Kuşkonar Kararı, Mücadelede Dönüm Noktası”, Bianet, 15 Kasım 2013, http://www.bianet.org/bianet/insan-haklari/151344-aihm-in-kuskonarkarari-mucadelede-donum-noktasi (Erişim Tarihi: 02.12.2013).

Weller, Marc, Iraq and the Use of Force in International Law, Oxford University Press, New York, 2010.

William Abresch, "A Human Rights Law of the Internal Armed Conflict: The European Court of Human Rights in Chechnya", The Journal of International Law, Vol. 16, No. 4, s. 741-767. 


\section{Summary}

There are various armed conflicts around the world, both as internal conflicts and as international conflicts. Apart from leading to crucial political, social and economic destructions, these conflicts also give rise to intensive human rights abuses at individual and social levels. In spite of the fact that there are many attempts to eliminate destructions and abuses mentioned above, in the field of international law and international humanitarian law, these attempts may sometimes fall behind the expected results.

Transitional justice is one of the fundamental means for struggling against difficulties resulting from armed conflicts. Transitional justice is regarded as a concept forming a link between conflict processes of the past and peaceful/negotiative processes of the present. It provides a basis for justice and accountability. Methods such as trials, truth seeking, reparations and institutional reforms (especially lustration policies) are used within transitional justice practices. International organizations and institutions play active role in putting transitional justice into practice. Courts such as the International Criminal Tribunal for Rwanda (ICTR), the International Criminal Tribunal for the Yugoslavia (ICTY) and International Criminal Court (ICC) are actors dealing with human rights abuses of the past.

Experiencing human rights abuses during the Second World War, Europe has made institutional and constitutional arrangements in order not to live same abuses again The European Convention of Human Rights (ECHR) is one of these arrangements. States, signing the ECHR as a component of European Human Rights System, have given ECtHRS authority to intervene in abuses beyond their own borders. Therefore, they have come to accept the supervision of trans-national mechanisms on their own national systems. In this framework, it seems possible to regard ECHR as a means of transitional justice.

Supervision through a judicial organ is a sui generis characteristic of the ECtHR. ECtHR has right to examine whether states comply with the principles of the ECHR or not. ECtHR also has power to award compensation in case of infringement. Respecting the principle of subsidiarity, ECtHR cannot make decisions in the name of national judiciary and it cannot intervene in the nations' own judicial discretions. Accordingly, ECtHR cannot act as though it is a fourth instance. ECtHR, as the major actor of the ECHR that was set up following conflict issues, plays significant role in the establishment and reinforcement of judicial systems of the states signing in the ECHR.

It is possible to point out that ECtHR has crucial decisions on non-international armed conflicts. Military operation by Turkey in Cyprus in 1974 and ongoing problems with Southern Cyprus, Chechenian conflict in Russia, Conflict between Turkish security forces and the PKK (Workers' Party of Kurdistan), The Bosnian War, are all related to armed conflicts.

ECtHR encourages conflicting parties to abide by the ECHR rather than play an active role in these processes. By doing so, ECtHR does not seek punishment but reparation and retrieval. ECtHR makes often references to Article 2, 3, 5, 7, 13, 34 and Article 1 of the Protocol 1 besides making references to other articles. In this context, it 
is also possible to notice that right to life (Article 2) and inhuman degrading treatment or punishment (Article 3) are the main articles to deal with past human rights abuses. "No effective investigation has been conducted" in connection with Article 2 is the most infringed article in human rights abuses of the states. Pain and anxiety of people whose relatives were exposed to violence (especially to forced disappearances) is emphasized by the ECtHR with respect to Article 3. On the basis of these articles, ECtHR makes references to the procedural commitments of the signatory states of the ECHR.

Abuses related with Article 5 are about missing persons on arrest and detention. Article 7 of the ECHR entitled "no punishment without law" is set forth in case of crimes against humanity. Abuses of Article 2, 3 and 5 are often correlated with Article 13. Article 38, titled as "examination of the case", is one of the most fundamental articles used by ECtHR for uncovering truths regarding human rights abuses. It imposes obligation for contracting parties to submit relevant information and documents regarding cases handled by ECtHR. States, unwilling to submit information and documents (or submitting deficient documents), have been found in violation many times by the ECtHR. The ECtHR, within the scope of the Article 1 Protocol 1, has given decisions for infringement in cases where there are problems in utilization of property rights without compensation for them. It is obvious that, ECtHR has a strong influence on human rights issues at national level. 